\title{
Mesoarchaean clockwise metamorphic P-T path from the Western Dharwar Craton
}

\author{
A. Dasgupta a , S.K. Bhowmik ${ }^{\text {a,* }}$, S. Dasgupta ${ }^{\text {b }}$, J. Avila ${ }^{\text {c }}$, T.R. Ireland ${ }^{\mathrm{c}}$ \\ a Department of Geology \& Geophysics, Indian Institute of Technology, Kharagpur 721 302, India \\ ${ }^{\mathrm{b}}$ Department of Earth Sciences, Indian Institute of Science Education E' Research- Kolkata, Mohanpur 741246, India \\ ${ }^{c}$ Research School of Earth Sciences, Australian National University, Canberra, ACT 2601, Australia
}

\section{A R T I C L E I N F O}

\section{Article history:}

Received 17 March 2019

Received in revised form 4 June 2019

Accepted 4 June 2019

Available online 8 June 2019

Keywords:

Mesoarchaean

Metamorphic P-T path

Monazite U-Pb dating

Dharwar Craton

Tectonics

\begin{abstract}
A B S T R A C T
In this study, we utilize high-alumina pelitic schist samples from the Holenarsipur Greenstone Belt, a component of the ca. 3.30-3.15 Ga Sargur Supergroup in the Western Dharwar Craton, South India to establish a Mesoarchaean metamorphic history in the terrane. On the basis of integrated textural, mineral compositional, metamorphic reaction history and P-T pseudosection modelling studies, garnet-monazite trace element thermometry and coupled monazite electron probe micro-analyzer and sensitive high-resolution ion microprobe $\mathrm{U}-\mathrm{Pb}$ dating results, we constrain for the first time a Mesoarchaean metamorphism along a hairpin clockwise metamorphic P-T path in the Dharwar Craton. The path reveals a two-stage prograde segment with an initial phase of heating accompanying burial ( $\mathrm{dP} / \mathrm{dT}$ gradient $\sim 30 \mathrm{bar} /{ }^{\circ} \mathrm{C}$ ) and a later phase of steep burial $(\Delta \mathrm{P}$ $\sim 1.1 \mathrm{kbar}, \mathrm{dP} / \mathrm{dT}$ gradient $\sim 110 \mathrm{bar} /{ }^{\circ} \mathrm{C}$ ), peak metamorphism at $7.5 \mathrm{kbar}, 640{ }^{\circ} \mathrm{C}$ and a post-peak, steep decompression stage $\left(\mathrm{P} \sim 6.3 \mathrm{kbar}\right.$ at $\left.635^{\circ} \mathrm{C}\right)$. Chemically zoned monazite grains shielded within garnet or occurring in low-strain matrix domains were formed in two stages during the Mesoarchaean metamorphism: (a) Monazite cores with relatively lower Y concentrations, higher Th/U ratios, a strong negative Eu anomaly; their REE partitioning relationships with the garnet inner rim reveal their crystallization was synchronous with the growth of garnet. (b) Monazite rims with higher Y and uraniferous compositions and lower Th/U ratios which, combined with Y and HREE enrichments in the outer rim of garnet, indicate their formation during the post-peak decompression stage associated with coupled decompositions of garnet and zircon. We correlate U-Pb monazite core and rim ages at $3144 \pm 7 \mathrm{Ma}$ and $3105 \pm 10 \mathrm{Ma}$ respectively with the timings of peak and retrograde metamorphism. Our findings, when evaluated with the available geological, isotopic, geochronological data of Meso- to Palaeoarchaean extant and extinct felsic crust as well as thermo-mechanical models, predict the ca.3.143.11 Ga metamorphism in the Holenarsipur Greenstone Belt as part of a widespread tectono-thermal event in the Western Dharwar Craton. The event marks late stages of sagduction tectonics in the craton as it evolves from a predominantly vertical to a horizontal shortening mode.
\end{abstract}

(c) 2019 Elsevier B.V. All rights reserved.

\section{Introduction}

Divergent opinions exist regarding the timing of initiation of "modern style" plate tectonics in the planet Earth and the indicator materials to be used from natural rock archive (summarised in Korenaga, 2013). Nevertheless, there is a general consensus that the switch over from "pre-subduction", plume-driven vertical tectonics to the "modern subduction" regime of horizontal plate motions is linked with a change in thermal regime from one of heat generation through radioactive decay to heat loss by conductive cooling (e.g. Herzberg et al., 2010; Michaut and Jaupart, 2007). Stern et al. (2016) propose that this tectonic transition took place in the time period between 3.2 and $2.8 \mathrm{Ga}$.

\footnotetext{
* Corresponding author.

E-mail address: santanu@gg.iitkgp.ac.in (S.K. Bhowmik).
}

Metamorphic rocks and well-constrained metamorphic P-T-t paths have emerged as potential tools to model Mesoarchean to Neoarchaean fossil tectonic settings (Cutts et al., 2014; Dziggel et al., 2002; François et al., 2014; Li et al., 2018; Moyen et al., 2006; Nicoli et al., 2015; Roberts and Santosh, 2018; Sizova et al., 2018; Van Kranendonk, 2011a). However, despite its potential significance, well-preserved amphibolite-granulite facies Mesoarchean crustal sections are rather rare in the global rock record, in part due to their incomplete preservation and also due to the effects of strong superposed Neoarchaean deformation and metamorphism that, in most cases, have obliterated the older history. One of the key challenges in applying metamorphic constraints to model the Meso- to Neoarchaean plate tectonic transition is to look through the veil of superposed orogenesis, and obtain Mesoarchaean time information in a metamorphic context. Monazite petrochronology that links monazite ages in a metamorphic context is 
particularly suitable in this context (Bhowmik et al., 2012, 2014; Engi et al., 2017; Foster et al., 2004; Gibson et al., 2004; Hermann and Rubatto, 2003; Kelsey et al., 2008; Kohn and Malloy, 2004; Montel et al., 1996; Pyle et al., 2001; Rubatto et al., 2001, 2013; Williams et al., 2007).

In this study, we address this issue using rocks from a Mesoarchaean, Sargur-type greenstone belt, locally referred to as the Holenarsipur Greenstone Belt (HGB) in the Western Dharwar Craton (WDC), South India. Although, previous studies have suggested a major tectonothermal and tectono-magmatic event in the WDC that led to the cratonization of the Dharwarian crust at ca. 3.0 Ga (Jayananda et al., 2013; Jayananda et al., 2015; Raith et al., 1982), the metamorphic conditions and P-T path of evolution of this Mesoarchaean event are yet to be established. On the other hand, preliminary geochronological investigations in the HGB and other segments of the Sargur supracrustals have recorded a pervasive latest Neoarchaean-earliest Palaeoproterozoic regional metamorphism in the WDC (Bouhallier, 1995; Jayananda et al., 2013). In order to resolve this issue of Mesoarchaean vs. Neoarchaean-earliest Palaeoproterozoic orogenesis in the WDC, we have adopted an integrated approach utilising reconstruction of the metamorphic P-T path through phase equilibria modelling, garnet-monazite thermometry and coupled Electron Probe MicroAnalysis (EPMA) and sensitive High-Resolution Ion Microprobe (SHRIMP) U-Pb monazite dating techniques. These are applied to a group of middle-amphibolite facies pelitic schist samples from the HGB. Combining trace element analyses of garnet and monazite, in situ Y, Th, and U chemical mapping of compositionally zoned and texturally well constrained monazite grains, results of chemical and SHRIMP U-Pb dating of same compositional domains of monazite and metamorphic P-T path constraint, we establish a Mesoarchaean metamorphism in the WDC. We discuss the geodynamic significance of this metamorphic event in the overall context of plate tectonic framework at this time period.

\section{Geological setting}

The WDC is located in the southern, cratonic part of the Indian Peninsula (Fig. 1a) and consists mainly of large swaths of tonalitetrondhjemite-granodioritic (TTG) gneiss (locally known as the Peninsular Gneiss complex) with intercalations of linear, generally N-S trending, belts of metamorphosed volcano-sedimentary units and associated granite greenstone belts (Swami Nath and Ramakrishnan, 1981). The TTG gneisses record three periods of felsic magmatism in the terrane at 3411-3276 Ma, 3230-3200 Ma and 3134-3103 Ma (Beckinsale et al., 1980, 1982; Bhaskar Rao et al., 1983, 2008; Guitreau et al., 2017; Jayananda et al., 2015; Peucat et al., 1993). Existence of an even older proto-crust up to $3610 \mathrm{Ma}$ in the WDC is indicated by published detrital and inherited U-Pb zircon ages in metasedimentary rocks and TTG gneisses (Guitreau et al., 2017; Hokada et al., 2013; Nutman et al., 1992; Sarma et al., 2012).

The volcano-sedimentary units are broadly subdivided into two types: the older (c.3.3-3.1 Ga) Sargur Supergroup and younger (2.91$2.56 \mathrm{Ga})$ Dharwar Supergroup, exposed as separate linear belts (Fig. 1a). The focus of this investigation is the older Sargur belt rocks (Fig. 1a) that are dominated by metamorphosed komatiite-basalt volcanics with rare felsic volcanics and interlayered sedimentary rocks (Swami Nath and Ramakrishnan, 1981). The antiquity of the Sargur supracrustals is indicated by the following observations: (a) Sm-Nd whole-rock isochron age of komatiite between $3352 \pm 110 \mathrm{Ma}$ (Jayananda et al., 2008) and $3125 \pm 120 \mathrm{Ma}$ (Mukherjee et al., 2012)

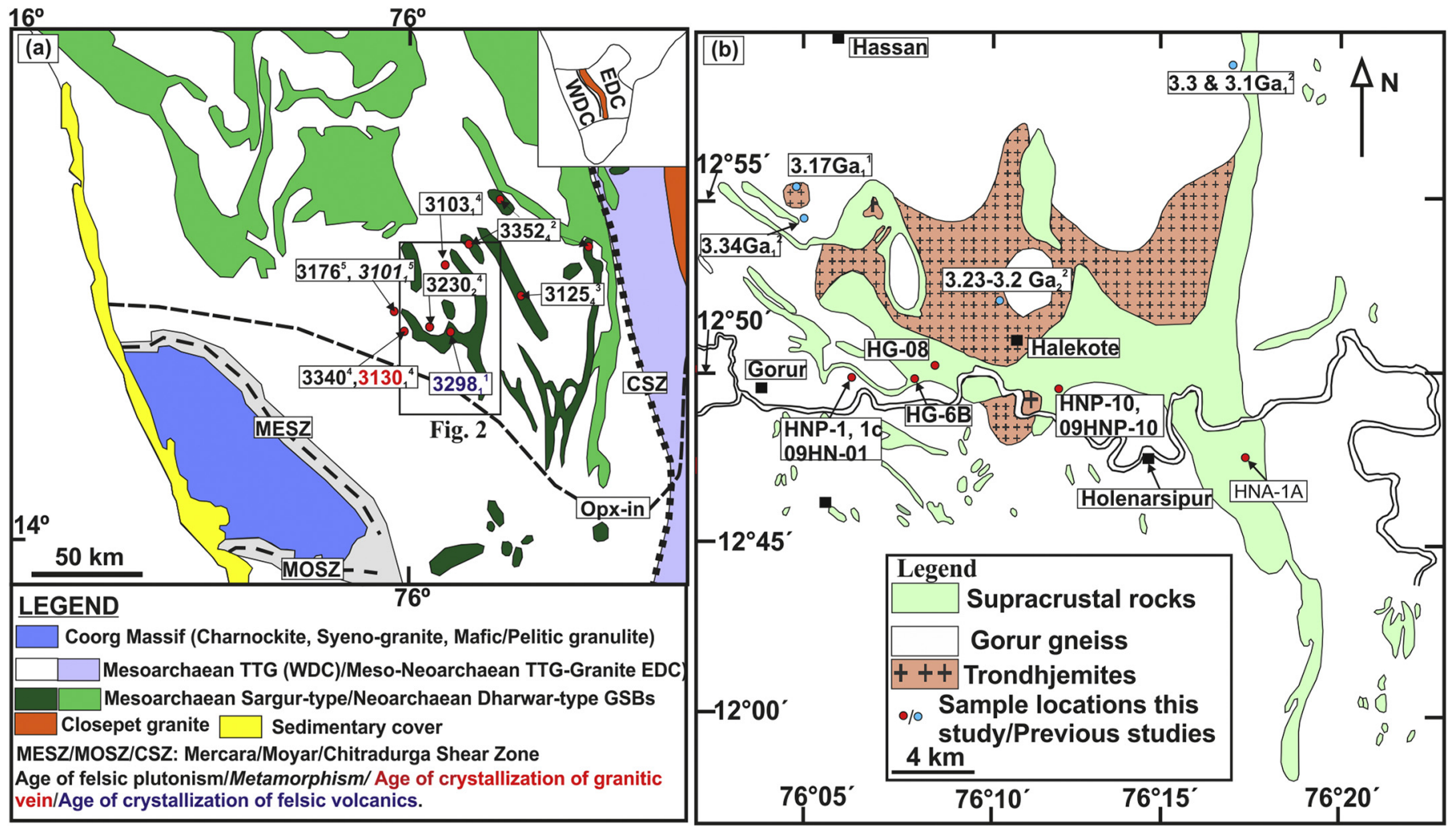

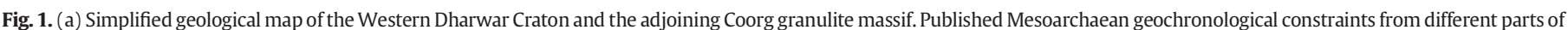

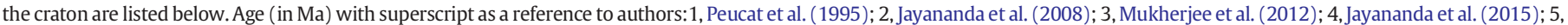

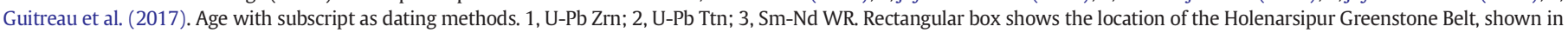

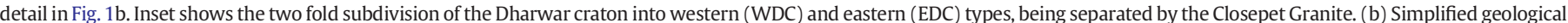

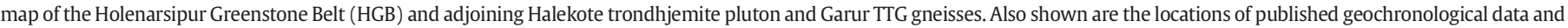

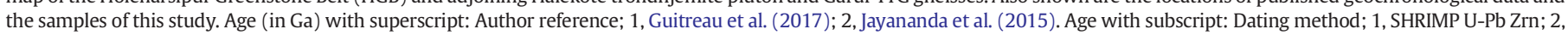
SHRIMP U-Pb Ttn. 
for the timing of eruption of komatiite lavas, (b) $3298 \pm 7 \mathrm{Ma}$ U-Pb zircon age of rhyolite volcanism in the HGB (Peucat et al., 1995), (c) detrital zircons in associated sedimentary rocks, from different parts of the Sargur belt ranging in age from 3580 to $2960 \mathrm{Ma}$ (Bhaskar Rao et al., 2008; Maibam et al., 2011; Nutman et al., 1992) and (d) intrusive granitoids in the Sargurs between 3.2 and $3.1 \mathrm{Ga}$ (Beckinsale et al., 1982; Guitreau et al., 2017; Jayananda et al., 2015; Peucat et al., 1993).

The metamorphic grade of the Sargur supracrustals increases from middle-amphibolite grade in the north to granulite grade in the southern-most parts of these belts (Janardhan et al., 1978, 1982; Jayananda et al., 2013; Raase et al., 1986; Rollinson et al., 1981; Srikantappa et al., 1985) (Fig. 1a). There is considerable debate regarding the timescales of metamorphism of the Sargur supracrustals and the WDC. Garnet Sm-Nd dating of medium-grade (Holenarsipur domain) and high-grade (type Sargur and adjoining Gundlupet domains) Sargurs (Fig. 1a) have yielded a uniform garnet growth age between 2.53 and 2.43 Ga (Bouhallier, 1995; Jayananda et al., 2013). This signifies a latest Neoarchaean-earliest Palaeoproterozoic regional metamorphic event in the WDC. In contrast, imprints of an older Mesoarchaean tectonothermal and tectono-magmatic event in the WDC have been inferred based on (a) resetting of $\mathrm{Pb}$ isotope ratios of detrital zircon in the Sargur supracrustals between 3.1 and 3.0 Ga (Lancaster et al., 2015; Nutman et al., 1992), (b) crustal anatexis and formation of a grey granite vein at 3.15 Ga within older ca. 3.35 Ga Garur gneiss (Jayananda et al., 2015), (c) development of zircon overgrowth at $2.99 \mathrm{Ga}$ in $3.2 \mathrm{Ga}$ potassic granites (Jayananda et al., 2013) and (d) metamorphic recrystallization of 3.2 Ga Halekote-equivalent trondhjemite gneiss at $3.1 \mathrm{Ga}$ (Guitreau et al., 2017).

We have chosen the Holenarsipur Greenstone Belt (HGB), the largest preserved exposure of the Sargur supracrustal unit, to find out the possible signatures of an older Mesoarchaean tectono-thermal event, despite an overprint of a strong Neoarchaean-Palaeoproterozoic regional event. This is because (a) the HGB and surrounding TTG gneisses constitute the oldest nucleus of the Dharwar craton (e.g. Radhakrishna and Naqvi, 1986), (b) previous studies have established an intrusive relationship between the Mesoarchaean trondhjemite pluton (e.g. Halekote pluton) and the Sargur supracrustals (e.g. Ramakrishnan and Viswanatha, 1981), (c) the dome and keel Garur gneiss-trondhjemite and greenstone outcrop pattern has been previously explained by a model of vertical tectonics of diapiric domes and sagducted greenstones (Bouhallier, 1995; Bouhallier et al., 1993, 1995). The timing of the vertical tectonics is, however, debatable and has been inferred to be of either Mesoarchaean (Bouhallier et al., 1993) or Neoarchaean (Bouhallier, 1995) age, and (d) pelitic schists of the HGB show the occurrences of chloritoid, garnet, staurolite and kyanite with plagioclase, two micas, ilmenite, rutile, quartz and accessory monazite (Bouhallier, 1995; Bouhallier et al., 1993; Bouhallier et al., 1995; Jayananda et al., 2013; Swami Nath and Ramakrishnan, 1981).

Bouhallier (1995) previously studied the metamorphic evolution of four distinct types of metapelitic schists (e.g. garnet-chloritoid schist, garnet-staurolite-epidote schist, staurolite-kyanite schist and garnetstaurolite-kyanite schist) from different strain domains in the HGB. The study revealed a broadly synkinematic growth of garnet with or without chloritoid, staurolite and kyanite at metamorphic peak and the same peak P-T estimates at $7-8 \mathrm{kbar}, 600{ }^{\circ} \mathrm{C}$ at linear troughs and foliation triple points in the greenstone. The foliation triple points have additionally recorded a prograde burial history from $3 \mathrm{kbar}, 470{ }^{\circ} \mathrm{C}$ to $7-8 \mathrm{kbar}, 600^{\circ} \mathrm{C}$, which was taken as evidence for the "diapiric instabilities model". Bouhallier (1995) suggested a ca. 2.5 Ga age of the metamorphism in the HGB. Summarising, the mineralogy and reaction textures in the Holenarsipur pelitic schists offer excellent opportunities to reconstruct the metamorphic P-T path of evolution, obtain texturallycontrolled monazite dates and interpret monazite dates in a metamorphic context.
Given this context of a strong regional scale ca. 2.5 Ga tectonothermal event affecting the HGB, we suggest that imprints of the older Mesoarchaean event are likely to be preserved in low-strain domains with respect to the last pervasive deformation event. In order to identify such samples with records of an earlier metamorphic history, we have carried out studies of metamorphism of 8 pelitic schist samples, spread over 5 locations in different parts from the southern margin of the HGB (sample locations in Fig. 1b). The pelitic schists, which are interlayered with fuchsite quartzite, ultramafic schist and amphibolite show a pervasive biotite + muscovite + chlorite \pm staurolite-defined metamorphic foliation. On the basis of careful textural analysis, we have classified them into two groups: (a) Samples recording syn- to post-kinematic growth of porphyroblasts (e.g. staurolite, garnet and kyanite) with respect to the foliation stated above, and similar to that recorded by Bouhallier (1995). Pelitic schists of this type (e.g. samples HNP-1, HNP-1C, 09-HN-01, HNA-1A, HG-6B, HG-8) have undergone peak kyanite-, and locally kyanite + garnet or staurolite-zone metamorphism, generally in the stability field of rutile. (b) In the second group, pelitic schists are polyphase metamorphosed with porphyroblasts having grown both pre- and post-kinematic with respect to the foliation (samples HNP-10 and 09-HNP-10). Although, this second group of polyphase metamorphosed samples are less abundant, these are potentially significant to constrain an earlier phase of metamorphism. For this reason, we have selected samples HNP-10 and 09-HNP-10 from two nearby outcrops in the same location, and also in close spatial association with the Halekote trondhjemite pluton (Fig. 1b) to obtain metamorphic P-T path information of the Mesoarchaean event, the primary focus of this study. We shall present the metamorphic P-T-t path information of the second group of samples that have preferentially registered the younger event in a separate publication.

\section{Methods of study}

\subsection{Analytical techniques}

\subsubsection{Electron Probe Micro-Analyzer (EPMA)}

Major-element mineral chemical compositions were measured using a CAMECA SX-100 electron microprobe fitted with four spectrometers at the Department of Geology and Geophysics, Indian Institute of Technology (IIT), Kharagpur. Analyses were performed with an accelerating voltage of $15 \mathrm{kV}$, a beam current of $15 \mathrm{nA}$ and a beam size of $\sim 1 \mu \mathrm{m}$ ( $\sim 5 \mathrm{~m}$ for feldspar and micas). Natural mineral standards were used for calibration, including orthoclase (for $\mathrm{K}$ and $\mathrm{Si}$ ), jadeite $(\mathrm{Na})$, wollastonite $(\mathrm{Ca})$, periclase $(\mathrm{Mg})$, hematite $(\mathrm{Fe})$, corundum $(\mathrm{Al})$, rhodonite $(\mathrm{Mn})$ and chromite $(\mathrm{Cr})$. Analytical variation within standards was kept at or below $\sim 1.5 \mathrm{wt} \%$ for primary standards. Representative mineral chemical analyses (presented in Table 1) were recalculated using the AX program (THERMOCALC software, v. 3.26).

For EPMA dating, monazites were analysed with the same EPMA at an accelerating voltage of $20 \mathrm{kV}$, a beam current of $150 \mathrm{nA}$, and a beam size of $1 \mu \mathrm{m}$. Spots for monazite analyses were selected on the basis of Y-, Th- and U- X-ray element maps. These were generated at $20 \mathrm{kV}$ and $50 \mathrm{nA}$, with 50-75 ms dwell times and step sizes at 0.2-0.7 $\mu \mathrm{m}$. X-ray data were calibrated against natural and synthetic standards. These were: yttrium aluminium garnet (YAG) for $\mathrm{Y} ; \mathrm{ThO}_{2}$ for Th; $\mathrm{UO}_{2}$ for $\mathrm{U}$; vanadinite for $\mathrm{Pb}$; synthetic silica-aluminium glass containing 4\% REE for La, Ce, Nd, Pr, Sm, Ho, Dy and Gd; apatite for P and Ca; corundum for $\mathrm{Al}$; hematite for Fe; Th-glass for $\mathrm{Si}$.

The measured X-ray lines for different elements and the attendant crystals were: Th M $\alpha, \mathrm{U} M \beta$ and $\mathrm{Ca} K \alpha$ (PET); Pb M $\alpha$, La-Ce L $\alpha$ and $\mathrm{P}$ K $\alpha$ (LPET); Pr-Nd-Gd-Ho L $\beta$, Sm-Dy L $\alpha$ and Fe K $\alpha$ (LIF); Y L $\alpha$, Al-Si $K \alpha$ (TAP). The counting times for these elements on the peak were: 10 s for $\mathrm{Si}, \mathrm{Al}, \mathrm{Fe}$ and P; 20s for Ca, La and Ce; 40s for Nd, Sm, Gd and Y; 60s for Dy and Ho; $200 \mathrm{~s}$ for Th and U and $300 \mathrm{~s}$ for Pb. Respective background intensities were measured on both sides of the peak for 
Table 1

Representative mineral chemical analyses in pelitic schists from the Holenarsipur Greenstone Belt, Western Dharwar Craton, India.

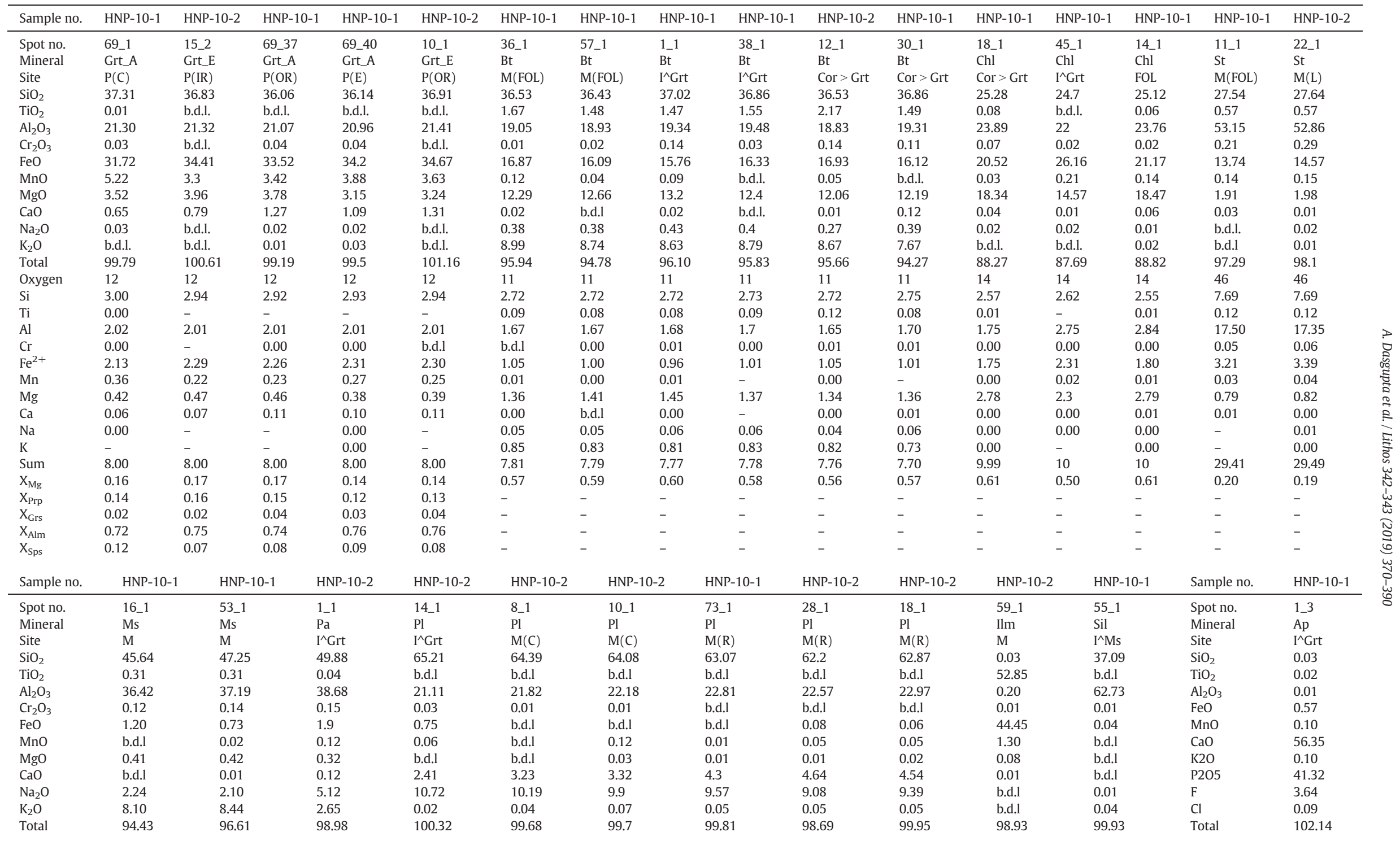

(continued on next page) 


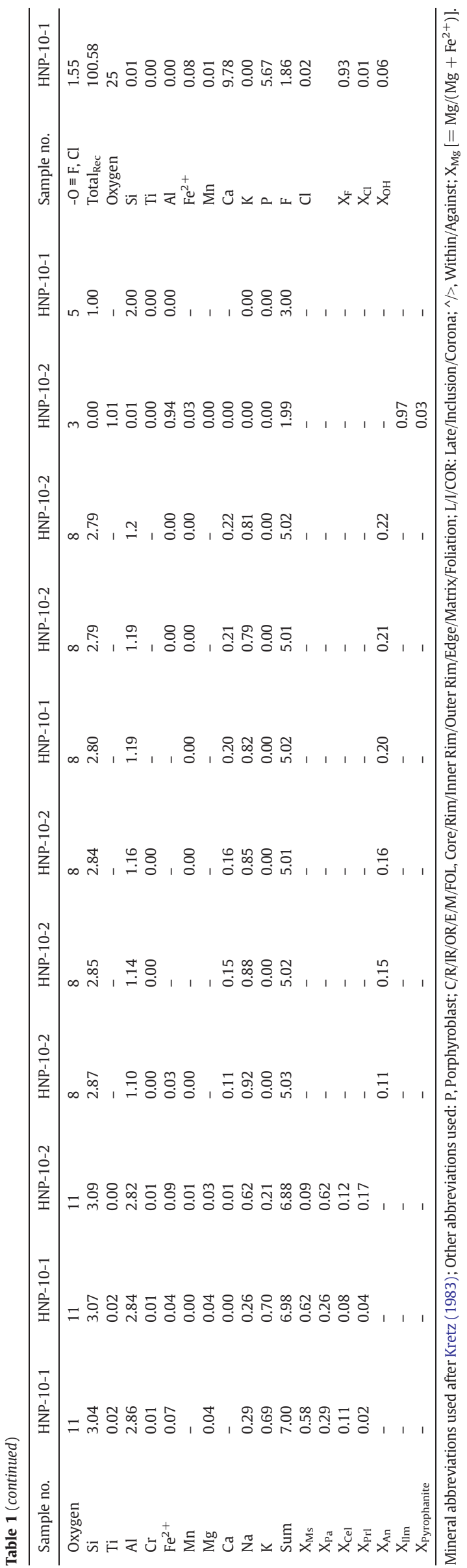

half the peak times. Interference of $\mathrm{Y} L \lambda$ on $\mathrm{Pb} \mathrm{M} \alpha$, Th $\mathrm{M} \zeta$ on $\mathrm{Pb} \mathrm{M} \alpha$ and Th $\mathrm{M} \gamma$ on $\mathrm{U} \mathrm{M} \beta$ were corrected after measuring the interfering lines during calibration and thereafter applying the overlap correction. Detection limits were $155 \mathrm{ppm}$ for Y, $145 \mathrm{ppm}$ for $\mathrm{Pb}, 380 \mathrm{ppm}$ for Th and $300 \mathrm{ppm}$ for $\mathrm{U}$. Further details of the monazite analytical protocol were presented in Bhowmik et al. (2014).

Prior to and during analytical sessions, analyses of an in-house reference monazite age standard (thermal ionization mass spectrometry age at $483 \pm 1 \mathrm{Ma}$, Chatterjee et al., 2010) were carried out periodically to monitor short-term systematic errors and to check for overall accuracy. This has yielded a long-term weighted mean age of $478 \pm 4 \mathrm{Ma}(2 \sigma$ error, MSWD $=0.57, \mathrm{n}=85$ ). Analyses of the monazite standard in two analytical sessions of this study yielded a mean age of $493 \pm$ $16 \mathrm{Ma}$ (MSWD $=0.54, \mathrm{n}=6$ ), which is within $3 \%$ of its long-term average. Relative age probability plots and weighted mean ages of monazite were computed with the Isoplot program (Ludwig, 2003). The complete monazite compositional dataset has been presented in the Supplementary Table S1.

\subsubsection{Laser ablation-inductively coupled plasma mass spectrometry (LA-} ICPMS)

Trace element measurements in garnet and monazite were carried out at the Department of Geology and Geophysics, IIT, Kharagpur using a Thermo-Fisher Scientific iCap-Q quadrupole-inductively coupled plasma mass spectrometer (ICPMS) attached to a new wave $193 \mathrm{Ar}-\mathrm{F}$ Excimer laser ablation system. The ablation was done at $5 \mathrm{~Hz}$ pulse frequency, $5 \mathrm{~J} / \mathrm{cm}^{2}$ beam energy density and spot sizes ranged from 30 to $40 \mu \mathrm{m}$ depending on the grain size. The analyses were performed in time resolved mode with each analysis consisting of 30s background measurement and 40s peak signal measurement. The ICPMS was optimized for maximum sensitivity on $\mathrm{Li}, \mathrm{Co}$, In, Th, and U using the NIST 612 reference glass. Calibration was done using NIST 610 and NIST 612 glass standards. Precision as determined from repeat analyses

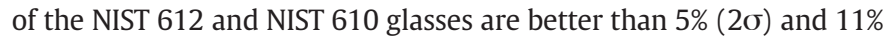
$(2 \sigma)$ respectively. Representative trace element analyses of garnet and monazite are presented in Table 2.

\subsubsection{SHRIMP U-Pb monazite dating}

The same monazite grains that were dated by the EPMA were also analysed with the Sensitive High Resolution Ion Micro-Probe Reverse Geometry (SHRIMP RG) housed at the Research School of Earth Sciences (RSES), Australian National University, Canberra. Regions of interest (8 $\mathrm{mm}$ diameter) with selected monazite and associated minerals were removed from standard polished thin sections with an ultrasonic disk drill. Grains of the Wendell monazite reference material (R. Tucker pers. commun.) were mounted in epoxy and polished; sections of the standard were then cut from the epoxy mount. The cut thin sections were then mounted on double-sided tape together with the reference standards and cast in $25 \mathrm{~mm}$ diameter epoxy mounts. The final mounts were then coated with gold to prevent sample charging during sputtering (Ireland and Williams, 2003).

The operating conditions and techniques for SHRIMP U-Th-Pb analysis of monazite followed that described by Ireland and Gibson (1998). The primary ion beam size was $30 \mu \mathrm{m}$ diameter, with an intensity of ca. $4 \mathrm{nA}$. Mass resolution was set to $5000 \mathrm{M} / \Delta \mathrm{M}$ (full width at $10 \%$ peak height), which is sufficient to resolve most significant molecular interferences. However, a potential isobaric interference from monazite ( $\mathrm{ThNdO}_{2}^{++}$at mass 204) cannot be resolved from ${ }^{204} \mathrm{~Pb}^{+}$(Ireland et al., 1999). Energy filtering discriminates against polyatomic molecules that are tightly constrained at the extraction energy $(10 \mathrm{keV})$, whilst maintaining the presence of atomic and oxide species with long energy distributions (Ireland, 1995). For this work we applied an energy offset of approximately $15 \mathrm{eV}$ which effectively removes the $\mathrm{ThNdO}_{2}^{++}$ interference from ${ }^{204} \mathrm{~Pb}^{+}$.

Isotopic ratios were measured by repeated cycles through the relevant molecular and nuclidic masses: $203\left(\left[{ }^{140} \mathrm{Ce}^{31} \mathrm{P}^{16} \mathrm{O}_{2}\right]^{+}\right)$, 
$204\left({ }^{204} \mathrm{~Pb}^{+}\right), 204.1$ (background), $206\left({ }^{206} \mathrm{~Pb}^{+}\right), 207\left({ }^{207} \mathrm{~Pb}^{+}\right), 208$ $\left({ }^{208} \mathrm{~Pb}^{+}\right), 232\left({ }^{232} \mathrm{Th}^{+}\right), 238\left({ }^{238} \mathrm{U}^{+}\right), 248\left({ }^{232} \mathrm{Th}^{16} \mathrm{O}^{+}\right)$and 254 $\left({ }^{238} \mathrm{U}^{16} \mathrm{O}^{+}\right)$. The $300 \mathrm{Ma}$ Wendell standard $\left({ }^{206} \mathrm{~Pb} /{ }^{238} \mathrm{U}\right.$ age analysed by P. Holden, pers. commun.) was used to normalize measured ${ }^{206} \mathrm{~Pb}^{+} /$ $\mathrm{U}^{+}$and ${ }^{208} \mathrm{~Pb}^{+} / \mathrm{Th}^{+}$ratios, with independent power-law calibrations for ${ }^{206} \mathrm{~Pb}^{+} / \mathrm{U}^{+}$[v. $\left.\left(\mathrm{UO}^{+} / \mathrm{U}^{+}\right)\right]$and ${ }^{208} \mathrm{~Pb}^{+} / \mathrm{Th}^{+}$[v. $\left.\left(\mathrm{ThO}^{+} / \mathrm{Th}^{+}\right)\right]$ (Ireland and Gibson, 1998). This was accommodated through data reduction with the well established ANU in-house software PRAWN and LLEAD. Data were compared to output from POXI, an in-house ANU LabView program that includes the data reduction methods of SQUID 1 (Ludwig, 2001), as well as PRAWN. For the purposes of this work, PRAWN/LLEAD was favoured because the full U-Pb, Pb-Pb, and Th- $\mathrm{Pb}$ assessment could be made in a consistent and established package (Ireland and Gibson, 1998).

All data have been corrected for common $\mathrm{Pb}$ on the basis of the ${ }^{204} \mathrm{~Pb} /{ }^{206} \mathrm{~Pb}$ ratio. Corrections for common $\mathrm{Pb}$ are relatively small with all unknown grains having $<0.2 \%$ common ${ }^{206} \mathrm{~Pb}$. Calculated $1 \sigma$ external spot to spot uncertainties for the Wendell standard for ${ }^{206} \mathrm{~Pb} /{ }^{238} \mathrm{U}$ is $2.3 \%$, and that for ${ }^{208} \mathrm{~Pb} /{ }^{232} \mathrm{Th}$ is $2.0 \%$. These uncertainties were combined with the analytical uncertainties of individual measurements. The reported ages are $>3000 \mathrm{Ma}$ and so the ${ }^{207} \mathrm{~Pb} /{ }^{206} \mathrm{~Pb}$ chronometer offers the highest precision (Table 4). Single analyses in the data table and concordia plot are presented with $1 \sigma$ errors, whereas uncertainties in weighted mean ages are quoted at $2 \sigma$, unless otherwise indicated.

\subsection{Metamorphic reconstruction}

\subsubsection{P-T Pseudosection modelling}

We quantify the mineral reaction pathways of the Mesoarchaean event using a calculated metamorphic phase diagram. We have adopted an approach of calculation of an equilibrium phase diagram using a Gibbs free energy minimization technique in P-T space (pseudosections) for fixed bulk rock compositions (Connolly, 1990). $\mathrm{P}-\mathrm{T}$ pseudosections have been computed in the model system $\mathrm{MnO}$ $\mathrm{TiO}_{2}-\mathrm{Na}_{2} \mathrm{O}-\mathrm{CaO}-\mathrm{K}_{2} \mathrm{O}-\mathrm{FeO}-\mathrm{MgO}-\mathrm{Al}_{2} \mathrm{O}_{3}-\mathrm{SiO}_{2}-\mathrm{H}_{2} \mathrm{O}$ (MnTiNCKFMASH) and using the PERPLEX software (v. 6.7.3., updated at June 8,2016 ) and the thermodynamic dataset of Holland and Powell (1998). The bulk rock composition has been adjusted for Ca by considering its amount stored in apatite. The following mixing models were applied: garnet: Ganguly et al. (1996); plagioclase: Newton et al. (1980); biotite: Powell and Holland (1999); chlorite: Holland and Powell (1998); chloritoid/staurolite: Holland and Powell (1998); white mica: Smye et al. (2010); ilmenite: Ideal mixing; cordierite:
Ideal mixing; alkali feldspar: Waldbaum and Thompson (1968). Kyanite, sillimanite, rutileand quartz are considered as pure phases. The metamorphic phase relationships for quartz and water saturated condition are presented in Fig. 4.

\subsubsection{Garnet-monazite thermometry}

We have additionally carried out garnet-monazite thermometry following the calibration of Pyle et al. (2001) to estimate peak metamorphic temperature and compare the result with that obtained by pseudosection modelling. Application of the thermometer requires compositional information of the phases involved in the chemically balanced reaction: YAG $(\mathrm{Y}+\mathrm{Al}$ Garnet $)+(\mathrm{OH})$-Apatite + (25/4) Quartz $=(5 / 4)$ Grossular $+(5 / 4)$ Anorthite $+3 \mathrm{YPO}_{4}$ (Monazite) $+(1 / 2)$ $\mathrm{H}_{2} \mathrm{O}$. The methodology is shown to have yielded meaningful temperature estimates in medium- and high-grade pelitic schists and migmatites respectively (Hallett and Spear, 2015; Pyle et al., 2001).

\section{Petrography and mineral chemistry}

\subsection{Petrography}

\subsubsection{Sample HNP-10}

This sample is a high alumina, garnet - staurolite - sillimanite - biotite - muscovite - chlorite - ilmenite - plagioclase - quartz schist with minor paragonite, monazite and zircon. We have studied two slices of the sample (named HNP-10-1 and HNP-10-2). Both the slices show a low abundance of garnet (1.5-3 modal\%) and are thinly banded with alternate layers rich in staurolite + ilmenite \pm chlorite, biotite + muscovite \pm chlorite and quartz + plagioclase, defining a pervasive foliation (Fig. 2a-b). The foliation wraps around garnet porphyroblasts (Fig. 2c). In the interfolial domain, there are coarse aggregates of staurolite (Fig. 2d) and locally muscovite (Fig. 2e). We consider these staurolite and muscovite aggregates to have pre-dated the pervasive foliation. The foliation is also overgrown by a later generation biotite (Fig. 2a), staurolite (Fig. 2f) and chlorite (Fig. 2g). Garnet is generally inclusionfree (Fig. 2c), excepting minor presence of biotite, paragonite (Fig. 2h), quartz and chlorite (Fig. 2i) within it. It is partially rimmed by biotite (Fig. 2a,i). Coarse matrix muscovite grains in the interfolial domain show presence of thick seams of fibrolitic sillimanite, particularly in its core (Fig. 2e). Thin flakes of muscovite in the foliation domain are characteristically free of sillimanite (Fig. 2j). In HNP-10, the analysed monazite grains occur in three textural settings (Fig. 2a): inclusions within garnet (grains M1 to M3 in HNP-10-1 and M1 in HNP-10-2), inclusions

Table 2

Representative trace element analyses of garnet and monazite in the pelitic schist sample HNP-10-1.

\begin{tabular}{|c|c|c|c|c|c|c|c|c|c|c|}
\hline Mineral & Grt & Grt & Grt & Grt & Grt & Grt & Mnz & Mnz & Mnz & Mnz \\
\hline Spot No. & 1 & 2 & 3 & 4 & 6 & 8 & 5 & 7 & 9 & 10 \\
\hline Site & $\mathrm{P}(\mathrm{IC})$ & $\overline{\mathrm{P}(\mathrm{OC})}$ & $\mathrm{P}(\mathrm{IR})$ & $\overline{\mathrm{P}(\mathrm{OR})}$ & $P(E)$ & $P(E)$ & $C$ & $C$ & $C$ & $C$ \\
\hline$Y$ & 198.4 & 178.0 & 125.4 & 88.9 & 111.2 & 116.9 & 11,237 & 10,534 & 11,371 & 10,253 \\
\hline La & b.d.l. & b.d.l. & b.d.l. & b.d.l. & 0.5 & 2.3 & 115,611 & 114,733 & 127,049 & $98,285.05$ \\
\hline $\mathrm{Ce}$ & b.d.l. & b.d.l. & b.d.l. & b.d.l. & 1.2 & 6.6 & 189,016 & 184,072 & 202,442 & 164,645 \\
\hline $\operatorname{Pr}$ & b.d.l. & b.d.l. & b.d.l. & b.d.l. & b.d.l. & 0.2 & 21,169 & 20,593 & 22,577 & 18,083 \\
\hline $\mathrm{Nd}$ & b.d.l. & 0.10 & $<0.15$ & b.d.l. & 0.1 & 3.3 & 83,649 & 78,642 & 89,857 & 74,382 \\
\hline $\mathrm{Sm}$ & 0.3 & 0.1 & 0.1 & 0.1 & 0.1 & 0.3 & 15,151 & 14,505 & 15,350 & 13,286 \\
\hline $\mathrm{Eu}$ & 0.2 & 0.1 & 0.1 & 0.1 & 0.2 & 0.2 & 2018 & 1911 & 2301 & 1803 \\
\hline Gd & 2.1 & 2.2 & 0.9 & 0.6 & 0.5 & 1.5 & 12,375 & 11,557 & 11,681 & 10,323 \\
\hline $\mathrm{Tb}$ & 1.5 & 1.6 & 0.9 & 0.6 & 0.5 & 0.6 & 1420 & 1292 & 1316 & 1236 \\
\hline Dy & 25.9 & 23.2 & 15.2 & 8.9 & 11.1 & 11.0 & 4916 & 4600 & 4568 & 4377 \\
\hline Ho & 8.3 & 7.9 & 5.7 & 3.8 & 4.9 & 5.0 & 486.7 & 447.2 & 461.2 & 421.3 \\
\hline $\mathrm{Er}$ & 27.8 & 27.2 & 21.5 & 18.3 & 25.5 & 25.6 & 565.9 & 531.2 & 564.7 & 472.2 \\
\hline $\operatorname{Tm}$ & 4.8 & 4.7 & 3.5 & 4.4 & 5.5 & 5.8 & 31.8 & 29.3 & 31.4 & 23.4 \\
\hline $\mathrm{Yb}$ & 35.7 & 32.6 & 28.2 & 41.5 & 55.1 & 58.8 & 102.1 & 96.9 & 115.9 & 75.7 \\
\hline $\mathrm{Lu}$ & 4.1 & 3.9 & 3.1 & 6.7 & 9.7 & 10.3 & 8.1 & 7.4 & 9.0 & 6.4 \\
\hline$(\text { HREE })_{\text {Tot }}$ & 110.2 & 103.4 & 78.9 & 84.9 & 112.7 & 118.5 & 19,905 & 18,561 & 18,747 & 16,935 \\
\hline Lu/Dy & 0.16 & 0.17 & 0.21 & 0.76 & 0.88 & 0.94 & 0.003 & 0.002 & 0.002 & 0.002 \\
\hline
\end{tabular}

Element concentrations in ppm; $(\mathrm{HREE})_{\mathrm{Tot}}=(\mathrm{Gd}+\mathrm{Tb}+\mathrm{Dy}+\mathrm{Ho}+\mathrm{Er}+\mathrm{Tm}+\mathrm{Yb}+\mathrm{Lu})$. 
within quartz in the interfolial domain (grain M5 in HNP-10-1) and in the foliation domain (grains M4, M6, M7 in HNP-10-1 and M2 to M4 in HNP-10-2). Whereas in the first two textural settings, shapes of monazite grains vary from partially elongated (Fig. 5a-b) through rectangular, ellipsoidal to ovoid (Fig. 5d-e), these are predominantly elongated in the foliation domain (Fig. 5g-h, j-k).

\subsubsection{Sample 09-HNP-10}

The high alumina pelite sample 09-HNP-10 is a staurolite - biotite muscovite - quartz schist, and differs from HNP-10 by the following textural attributes: (a) presence of kyanite (Fig. 2k) and rutile (Fig. 21), (b) absence of garnet, sillimanite, paragonite and ilmenite and (c) absence of mineralogical layering. The matrix foliation is defined by oriented muscovite, biotite, staurolite and rarely chlorite (Fig. $2 \mathrm{~m}$ ). Porphyroblasts of kyanite overgrow the foliation. There are two textural varieties of staurolite in the sample: (a) Staurolite ${ }_{1}$ occurs as a protected inclusion within kyanite (Fig. 2k). (b) Staurolite ${ }_{2}$, often intergrown with quartz partially rims biotite or its aggregates enclose kyanite relics (Fig. 2n). In 09HNP-10, all the monazite grains occur in the foliation domain with shapes varying from elongated through ovoid to amoeboid.

\subsection{Mineral chemistry}

Mn-, Mg-, Ca- and Fe-X-ray element images of two representative garnet grains in the HNP-10-1 and HNP-10-2 show a uniform feature of Mn-rich core and Mn-poor rim and a rim-ward increase in $\mathrm{Mg}, \mathrm{Ca}$ and Fe contents (Fig. 3a-h), which are also reflected in the compositional profiles (Fig. 3i-r). This rim-ward depletion in spessartine (12 $\rightarrow$ 07-08 mol\%) and minor enrichments in pyrope $(14 \rightarrow 15)$ and $\mathrm{X}_{\mathrm{Mg}}$ $(16 \rightarrow 17$ ) (Table 1$)$ contents in garnet are attributed to compositional zoning due to prograde garnet growth. One characteristic feature of garnet in this sample is the rim-ward enrichment in grossular content (02 $\rightarrow 04)$. The outermost garnet rim ( 115-250 $\mu \mathrm{m}$ wide) in contact with biotite shows a fall in $\mathrm{X}_{\mathrm{Mg}}(17 \rightarrow 14)$ and grossular contents $(04 \rightarrow 03)$.

A garnet core in sample HNP-10-1 is enriched in heavy rare earth elements (HREE, Gd to Lu) relative to its inner rim (Table 2, Fig. 3s). Collectively and individually, all HREE elements and Y show a steady decrease in their concentrations from core to inner rim (Fig. 3t-v). The outermost garnet rim is, however, enriched in HREE and Y (Fig. 3t-u), which is also reflected in the changing Lu/Dy ratios from core/inner rim $(\sim 0.16-0.21)$ to outer rim $(\sim 0.88-0.93)$. We attribute the compositional zoning in garnet, reflecting core to rim depletions in HREE and Y contents, and broadly resembling a bell-shaped REE distribution, to prograde garnet growth (Hickmott and Shimizu, 1990; Otamendi et al., 2002). The spikes in HREE and Y at the outermost rim of garnet are explained by intragranular back-diffusion during garnet dissolution.

Biotite in the foliation domain is slightly more magnesian (0.57$0.59)$ than it its occurrence as a partial rim around garnet $\left(\mathrm{X}_{\mathrm{Mg}}=\right.$ $0.56-0.57$ ) (Table 1). Included biotite in garnet has $\mathrm{X}_{\mathrm{Mg}}$ of $0.58-0.60$. Both included plagioclase in garnet $\left(\mathrm{An}_{11}\right)$ and matrix plagioclase are oligoclase $\left(\mathrm{An}_{15-22}\right)$ with the matrix variety showing reverse zoning $\left[\mathrm{An}_{15-16}(\mathrm{C}) \rightarrow \mathrm{An}_{21-22}(\mathrm{R})\right]$.

Matrix muscovite is generally sodic $\left(\mathrm{Ms}_{58-62} \mathrm{~Pa}_{26-29} \mathrm{Cel}_{8-11} \mathrm{Prl}_{02-04}\right)$ in composition. Paragonite has a composition of $\mathrm{Pa}_{62} \mathrm{Cel}_{12} \mathrm{Ms}_{09} \operatorname{Prl}_{17}$.

Staurolite is compositionally homogeneous at $\mathrm{X}_{\mathrm{Mg}}=0.20$. Matrix chlorite is more magnesian $\left(\mathrm{X}_{\mathrm{Mg}}=0.61\right)$ than that included within garnet $\left(\mathrm{X}_{\mathrm{Mg}}=0.50\right)$. Apatite inclusions in garnet are fluorapatite $\left(\mathrm{X}_{\mathrm{F}}=\right.$ 0.93 ) with minor hydroxylapatite content $\left(\mathrm{X}_{\mathrm{OH}}=0.06\right)$.

\subsection{Mineral reaction history}

We now use the textural and mineral compositional features to infer the possible reaction pathways that shaped the metamorphic evolution of the HGB. While both the samples record a common biotite + muscovite + staurolite + chlorite-defined foliation, mineral assemblage pre- and post-dating the foliation is different and is differentially preserved in the two samples. In HNP-10, porphyroblastic garnet (together with its included phases such as biotite, chlorite and paragonite) (Fig. 2h), coarse staurolite aggregates (Fig. 2d) and muscovite with thick seams of fibrolitic sillimanite inclusions (Fig. 2e) have developed preceding the pervasive deformation event. Although of fragmentary in nature, these textural and compositional attributes when applied together attest to three distinct metamorphic stages: (a) a partially preserved prograde heating stage, as indicated by an early stability of chlorite (Fig. 2a, i), biotite (Fig. 2h) and paragonite (Fig. 2h), and formation of growthzoned garnet (Fig. 3) following a model reaction, R1 (Table 3), (b) peak metamorphism, represented by garnet and staurolite, together with ilmenite, muscovite, biotite, sodic plagioclase and quartz, and (c) a garnet decomposition stage, producing biotite, sillimanite and relatively calcic plagioclase according to a model reaction, garnet + muscovite + plagioclase $_{1} \rightarrow$ biotite + sillimanite + plagioclase $_{2}$ (R2a, Table 3 ). This reaction is supported by features such as partial biotite rim around garnet (Fig. 2i), development of fibrolitic sillimanite in muscovite (Fig. 2e), depletion in grossular contents in garnet rim and reverse zoning in plagioclase $\left(\mathrm{An}_{15-16 \rightarrow 21-22}\right)$. Additional support for the decomposition of garnet comes from the trace element zoning in the mineral (Fig. 3sv). In the garnet-absent domain, sillimanite can also be formed via the reaction, staurolite + muscovite + quartz $\rightarrow$ biotite + sillimanite $+\mathrm{H}_{2} \mathrm{O}$ (R2b, Table 3).The occurrences of staurolite (Fig. 2c), chlorite (Fig. 2b) and sillimanite-free muscovite (Fig. 2j) in the foliation domain indicate a low-temperature hydration event, according to the model reaction, sillimanite + biotite $+\mathrm{H}_{2} \mathrm{O} \rightarrow$ chlorite + staurolite + muscovite (R3, Table 2).

Sample 09HNP-10, in contrast, has preferentially preserved a mineral reaction history following the foliation development. Textural features record a two stage mineral assemblage development in the rock: (a) the formation of kyanite (Fig. 2k) and rutile (Fig. 2l) from the decomposition of staurolite $_{1}$ (Fig. $2 \mathrm{k}$ ) and ilmenite as part of a second kyanite-zone prograde burial and heating event and (b) retrograde regrowth of staurolite 2 (Fig. 2n) with or without chlorite after kyanite (Table 3 for model reactions). For ease of description, we name these two prograde burial events, pre- and post-dating the recorded deformation event as $\mathrm{M}_{1}$ and $\mathrm{M}_{2}$ respectively (Table 3). Summarising, the two investigated samples together record a polyphase metamorphic evolution of the terrane.

\section{Calculation of metamorphic phase diagram and reconstruction of metamorphic P-T path}

Even in the context of a possible polyphase metamorphic history of the HGB, this early stage of metamorphic evolution, which has mostly escaped from later equilibration is unlike that previously documented by Bouhallier (1995). We consider this ideally suited to explore and link with a possible older Mesoarchaean tectonothermal history of the terrane. For this, we utilize sample HNP-10 for its excellent record of multistage reaction history of the $\mathrm{M}_{1}$ event, the focus of this study.

The phase diagram predicts an early stability of staurolite before garnet (at $\mathrm{P}<7.5 \mathrm{kbar}$ ) and biotite during prograde heating along a medium-pressure-medium-temperature (MP-MT) thermal gradient, consistent with their thermal and baric stabilities in high-alumina pelite bulk rock composition as in HNP-10 (Fig. 4a). The P-T field of the $\mathrm{M}_{1}$ peak metamorphic assemblage garnet + biotite + muscovite + staurolite + ilmenite + plagioclase + quartz is demarcated by the kyanite-in curve at higher $T\left(T>640-650{ }^{\circ} \mathrm{C}\right)$, the rutile-in curve at higher $\mathrm{P}(\mathrm{P}$ $>8 \mathrm{kbar}$ ), the garnet-out and sillimanite-in curves at lower $\mathrm{P}$ ( $\mathrm{P}$ between 6.0 and $6.8 \mathrm{kbar})$ and the paragonite-out curve at lower $T(T<600-640$ $\left.{ }^{\circ} \mathrm{C}\right)$ (Fig. 4b). Assuming the bulk rock has not been significantly fractionated prior to garnet growth, we constrain the $P-T$ condition of the first appearance of garnet by knowing the compositions of the earliest stabilized prograde garnet core and applying the isopleth thermobarometry approach (after Vance and Mahar, 1998). Intersection of the three 

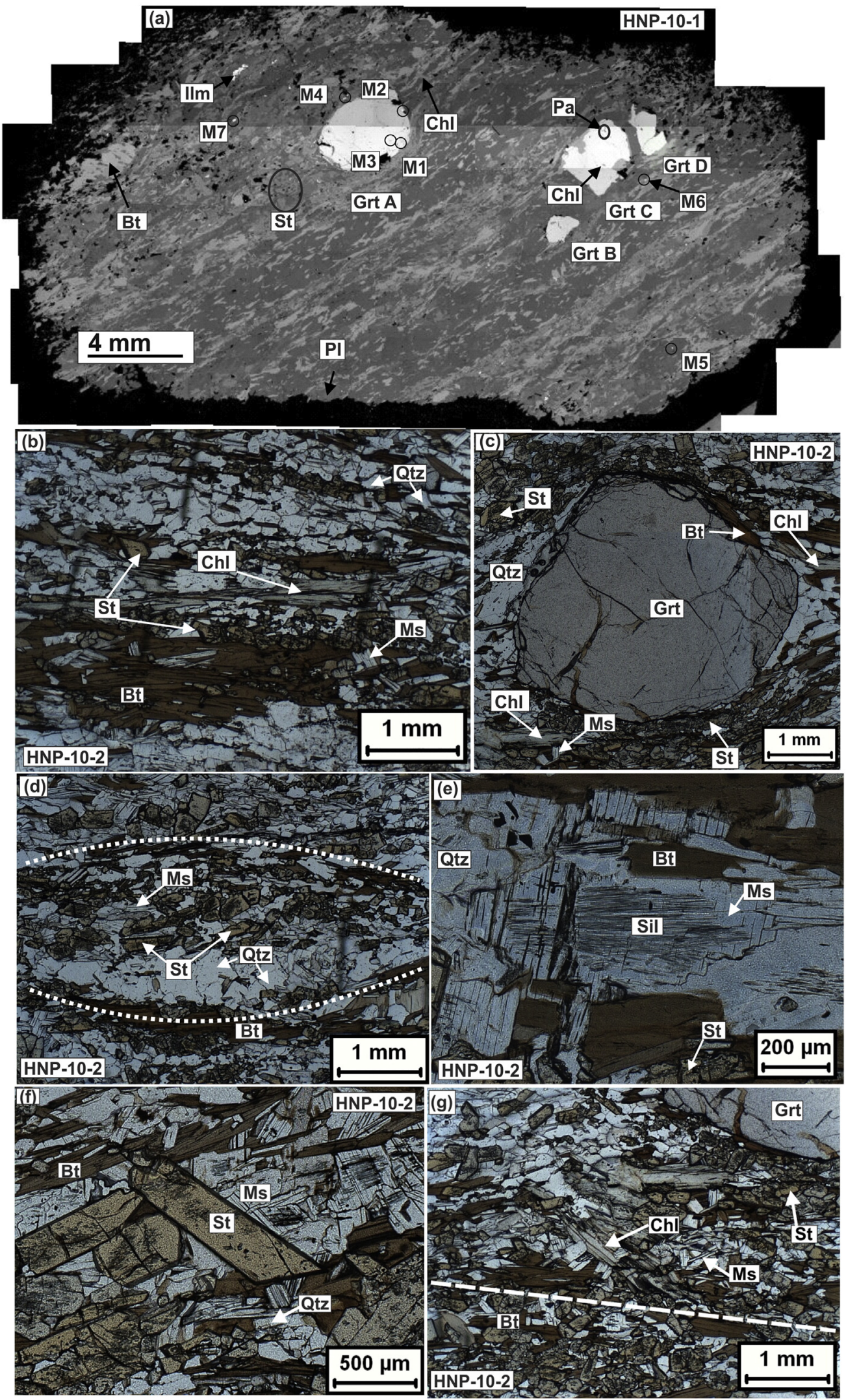

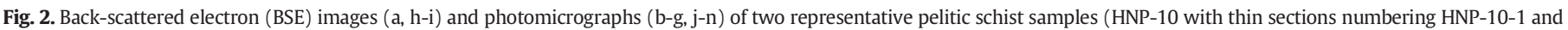
HNP-10-2 and 09-HNP-10), showing key textural features. Mineral abbreviations used in this and other figures are after Kretz (1983). (a-j) Sample HNP-10 showing the development of a thinly banded schistosity (a-b) that wraps around Grt porphyroblast (c). Coarse aggregates of St (d) and locally Ms. (e) occur in the interfolial domains. The schistosity is overgrown by texturally late Bt (a), St (f) and Chl (g). Grt with rare inclusions of Bt, Pa (h), Qtz and Chl (i) is partially rimmed by Bt (a, g) at places. Whereas thick seams of fibrolite occur at the core of the interfolial Ms. (e), these are absent in the foliation-defining Ms. grains (j). Locations of monazite grains (M-1, M-2, M-3, M-4, M-5, M-6 and M-7) are marked in Fig. 2a. (k-n) Sample 09-HNP-10 showing the occurrences of large Ky porphyroblast, locally with included St (k) and Rt (l). The porphyroblasts overgrow a Bt + Ms. \pm Chl- defined schistosity (m). Aggregates of a texturally later generation of St enclose relics of Ky (n). 

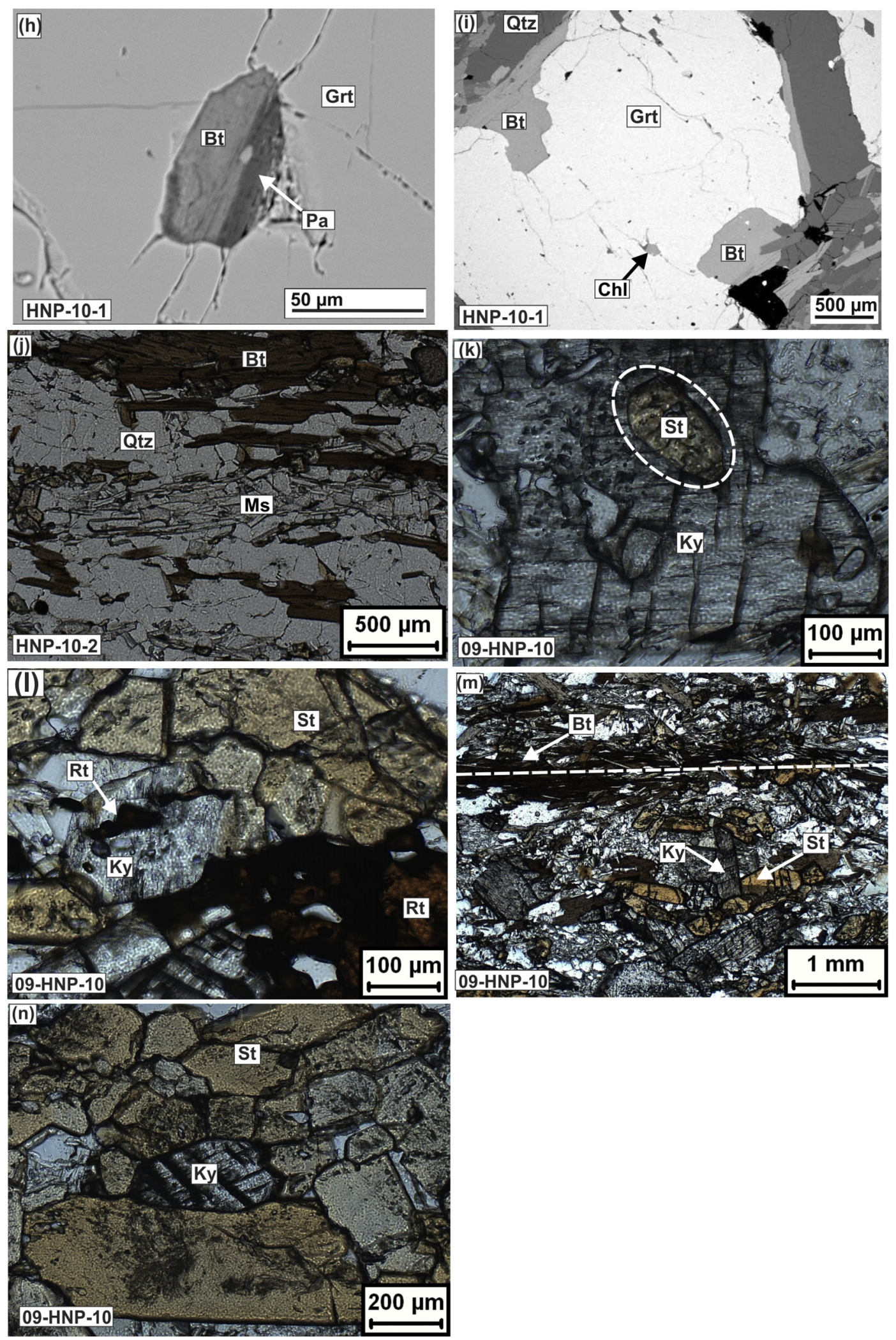

Fig. 2 (continued). 

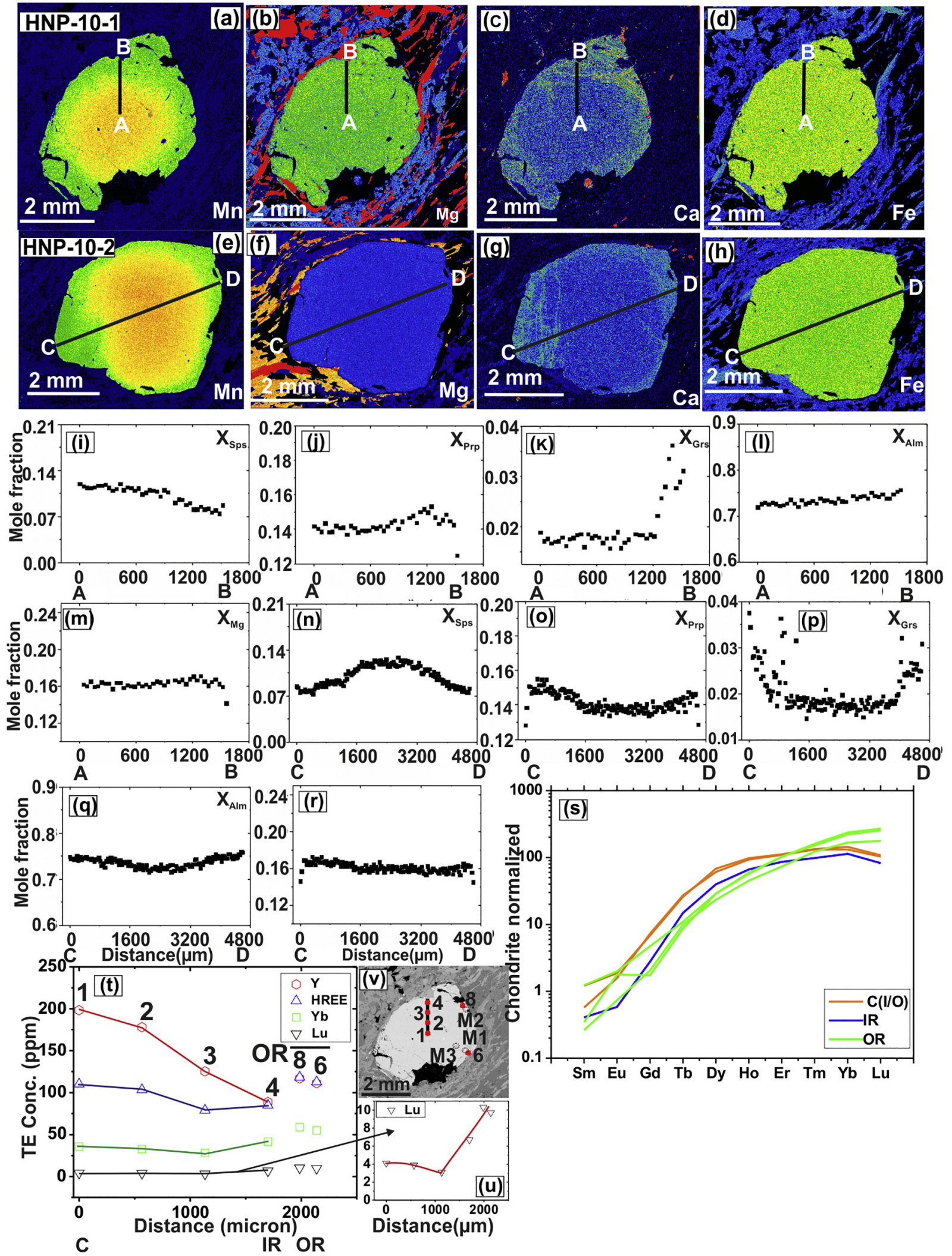

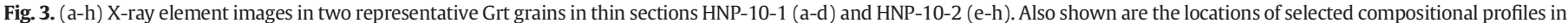

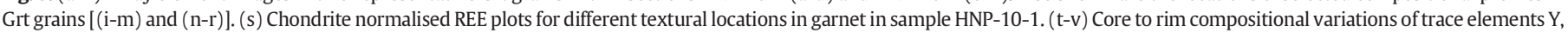
total HREE contents, Yb and Lu in garnet. Numbers refer to textural locations of the analytical spots in garnet, shown in Fig. (v). The Lu plot is magnified in Fig. (u).

compositional isopleths of garnet, $\mathrm{X}_{\operatorname{Prp}}\left(\operatorname{Prp}_{14}\right), \mathrm{X}_{\mathrm{Grs}}\left(\mathrm{Grs}_{02}\right)$ and $\mathrm{X}_{\mathrm{Sps}}$ $\left(\mathrm{Sps}_{12}\right)$ that are contoured in the calculated phase diagram, yields a $P$ $T$ condition of $\sim 6.4 \mathrm{kbar}$ and $630^{\circ} \mathrm{C}$ for the first appearance of garnet in the rock (Fig. 4b). Due to relatively low modes of garnet ( 1.5-3\%) in the rock, we also consider that bulk rock fractionation due to garnet growth is unlikely to be significant (e.g. Marmo et al., 2002) making it 
possible to use the inner rim composition of growth zoned garnet to estimate the peak P-T condition of metamorphism. The assumption, if valid, would yield tight intersections between the compositional isopleths of garnet and other phases (e.g. Evans, 2004).

As discussed in the mineral chemistry section, the Mg-Fe composition of the outer rim of growth-zoned garnet has been partially reset due to the decomposition of garnet (Fig. $3 \mathrm{~m}, \mathrm{r}$ ). This implies that the maximum pyrope content in garnet outer rim is likely to be higher than that measured $\left(\operatorname{Prp}_{15.5}\right)$. We have estimated this pyrope content at $\sim 16 \mathrm{~mol} \%$ by projecting the core-rim pyrope profile up to a distance where $\mathrm{X}_{\mathrm{Grs}}$ is at a maximum ( $\mathrm{Grs}_{04}$ ) (inset of Fig. $4 \mathrm{~b}$ ). We use these garnet $\left(\operatorname{Prp}_{16} \mathrm{Grs}_{04} \mathrm{Sps}_{07}\right)$ and matrix biotite $\left(\mathrm{X}_{\mathrm{Mg}}=0.57\right)$ compositions to calculate $P$ - $T$ conditions of peak metamorphism. Tight intersections of these compositional isopleths of garnet and biotite $\left(\Delta \mathrm{T} \sim 15^{\circ} \mathrm{C} ; \Delta \mathrm{P} \sim\right.$ $0.3 \mathrm{kbar}$ ) have yielded a $P-T$ value of $\sim 7.5 \mathrm{kbar}, 640{ }^{\circ} \mathrm{C}$ (Fig. 4b), which is taken as the estimate of peak metamorphism in the HGB. The P-T estimate is in good agreement with the texturally constrained kyaniteand rutile-absent peak metamorphic assemblage.

We now apply the reconstructed metamorphic reaction pathways and estimated $P$ - $T$ conditions during garnet growth to deduce the metamorphic $P-T$ path of evolution of the $\mathrm{M}_{1}$ event. The dispositions of paragonite-out, chlorite-out and garnet-in curves and garnet mode contours reveal two segments of the prograde $P-T$ path: (a) segment $1 \mathrm{a}$, indicating heating accompanying loading intersects chlorite-out, paragonite-out and garnet-in curves in a sequence (Fig. 4c). This is supported by textural features such as the presence of chlorite and paragonite inclusions within garnet and complete absence of paragonite in the matrix. The phase diagram predicts a metamorphic sequence of an early stability of paragonite and chlorite and subsequently their complete removal in the mineral assemblages along path 1a (Fig. 4c). (b) Segment 1b with a steep $\mathrm{dP} / \mathrm{dT}$ gradient marks a phase of prograde garnet growth, also supported by intersections of progressively higher garnet mode contours (Fig. 4c). There are three possible $P$ - $T$ pathways of evolution following the growth of garnet (Fig. 4c): (a) a phase of near-isobaric cooling (Path 2), (b) a segment of heating accompanying decompression followed by decompression and cooling (Path 3) and (c) a segment of near-isothermal decompression (Path 4). Path 2 , which intersects increasing garnet mode contours can be discounted as it does not explain the post-peak reaction history of decomposition of garnet (Fig. 4c) and appearance of sillimanite (Fig. 2e). Path 3 is also unlikely as the segment of heating at lower pressure will involve the formation of kyanite, which is not recorded in the sample. We favour option (c) since the steep decompression path (path 4) intersects progressively decreasing garnet and muscovite and increasing biotite and plagioclase mode contours (Fig. 4c), culminating in the appearance of sillimanite and not kyanite at the lowest pressure end. This is consistent with the construed post-peak reactions (R2a,b, Table 3). Reappearance of chlorite and staurolite via reaction R3 (Table 3 ) in the foliation domain reflects a low- $T$ hydration stage, which can be part of the same retrograde $P-T$ path and marking a phase of postdecompressional cooling. Alternatively, the syntectonic formation of chlorite and staurolite can be related with the temporally unrelated $\mathrm{M}_{2}$ event. Nevertheless, our study reveals that this progressive change in P-T vectors from heating accompanying loading (Path 1a) through isothermal burial (Path 1b) and finally to isothermal decompression (Path 4) defines a clockwise $P-T$ path of evolution of the $\mathrm{M}_{1}$ event in the HGB (Fig. 4c).

\section{Monazite EPMA dating}

\subsection{Texture, compositional zoning and geochronological results}

We have analysed a total of 97 spots in 16 monazite grains from 3 thin sections [7 grains (M1 to M7) in HNP-10-1, 4 grains (M1 to M4) in HNP-10-2 and 5 grains (M1 and M3 to M6) in 09HNP-10] belonging to 2 samples of pelitic schist (HNP-10 and 09-HNP-10). The analyses reveal monazite grains of two age groups: (a) Mesoarchaean monazite grains generally occur as inclusions in garnet (e.g. Fig. 5a for a representative monazite grain M1; see Supplementary Fig. S1 for other examples) and rarely in the matrix (e.g. monazite grain M5, Fig. 5d). (b) Neoarchaean to Earliest Palaeoproterozoic monazite grains characteristically occur as discrete elongated grains in the matrix, aligning parallel to the $\mathrm{M}_{2}$ foliation domain (Fig. $5 \mathrm{~g}$, j). Cores of some of these monazite grains show the presence of remnant Mesoarchaean monazite (Fig. 5h-i, k-l). We interpret the Neoarchaean to Earliest Palaeoproterozoic monazite grains to have originated due to dissolution-reprecipitation of the Mesoarchaean monazite and to have grown synchronously with the $\mathrm{M}_{2}$ metamorphic event. In this study, we have presented the textural, compositional and age information of the Mesoarchaean monazite grains (Figs. 5, 6, 7). The details of Neoarchaean to Earliest Palaeoproterozoic monazite geochronology will be presented in a separate publication.

X-ray element (Y, Th and U) imaging (Supplementary Fig. S1 for details and Fig. 5b, e, h, k for representative Y-X-ray element images) and individual spot chemical analyses (Supplementary Table S1) together reveal compositional zoning in the Mesoarchaean monazite grains. Despite compositional overlaps, textural and compositional features attest to two types of compositional domains, CD1 and CD2. Compositional variations in these domains are controlled by the operation of a dominant cheralite substitution vector $(\mathrm{REE}=\mathrm{Ca}+\mathrm{Th})$ (Fig. $5 \mathrm{~m})$.

CD1 is documented only in HNP-10 in the cores of composite monazite crystals, generally occurring as inclusions in garnet (Fig. 5a), matrix quartz from the interfolial domain (Fig. 5d) and staurolite from the foliation domain (Fig. $5 \mathrm{~g}$ ). The domain is marked by low-moderate Th $\left(\mathrm{ThO}_{2}=2.5-6.0 \mathrm{wt} \%\right)$, low-moderate $\mathrm{Y}\left(\mathrm{Y}_{2} \mathrm{O}_{3}=1.2-1.5 \mathrm{wt} \%\right)$ (Fig. 5b, e, h. k), very low $\mathrm{U}\left(\mathrm{UO}_{2}=0.2-0.4 \mathrm{wt} \%\right.$ ) contents (Fig. $5 \mathrm{n}$ and Supplementary Fig. S1 for complete information), and coupled relatively higher $\mathrm{Th} / \mathrm{U}$ ratios (8-19) but lower $\mathrm{X}_{\mathrm{YPO} 4}$ contents (Fig. 5o).

Table 3

A summary of key metamorphic mineral assemblages, mineral compositions and mineral reaction history in metapelitic schists from the Holenarsipur Greenstone Belt, WDC.

\begin{tabular}{|c|c|c|c|}
\hline $\begin{array}{l}\text { Sample/Met }{ }^{\text {ic }} \text { events/Bulk } \\
\text { composition/location }\end{array}$ & Metamorphic assemblage & Mineral chemistry & $\begin{array}{l}\text { Metamorphic } \\
\text { reactions }\end{array}$ \\
\hline $\begin{array}{l}\text { HNP- } 10 ; \mathrm{M}_{1}-\mathrm{M}_{2} ; \mathrm{MnO}=0.08 ; \mathrm{Al}_{2} \mathrm{O}_{3} \\
\quad=21.01 ; \mathrm{Ca}^{\#}=22 ; \mathrm{Mg}^{\#}=42 ; \\
\text { Lat: } 12^{\circ} 49^{\prime} 52^{\prime \prime}, \text { Lon: } 76^{\circ} 12^{\prime} 16^{\prime \prime}\end{array}$ & $\begin{array}{l}\mathrm{M}_{1 \mathrm{PR}}: \mathrm{Pa}, \mathrm{Bt}, \mathrm{Qtz}, \mathrm{Chl},(\mathrm{St}, \mathrm{Ms}) ; \mathrm{M}_{1 \mathrm{P}}: \mathrm{Grt}+\mathrm{St}(+ \\
\mathrm{Ms} .+\mathrm{Bt}+\mathrm{Pl}+\mathrm{Ilm}+\mathrm{Qtz}) ; \mathrm{M}_{1 \mathrm{R}}: \mathrm{Bt}+\mathrm{Sil}+ \\
\text { Ca-Pl; } \mathrm{M}_{2}(\mathrm{FOL}): \text { Chl, St, Bt, Ms., Qtz }\end{array}$ & 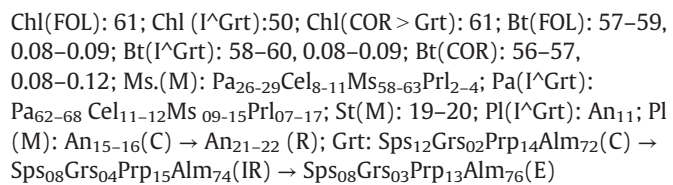 & $\begin{array}{l}\mathrm{M}_{1} \text { : Chl-out, Pa-in } \\
\rightarrow \text { Grt-in(R1) } \rightarrow \\
\text { Sil-in (R2a,b) } \\
\mathrm{M}_{2}: \text { Chl-in (R3) }\end{array}$ \\
\hline $\begin{array}{l}\text { 09-HNP-10; } \mathrm{M}_{2} ; \text { Lat: } 12^{\circ} 49^{\prime} 52^{\prime \prime} \text {, } \\
\text { Lon: } 76^{\circ} 12^{\prime} 16^{\prime \prime}\end{array}$ & $\begin{array}{l}\mathrm{M}_{2} \text { (FOL): St, Chl, Ilm, Bt, Ms., Qtz; } \mathrm{M}_{2 \mathrm{P}}: \mathrm{Ky}+\mathrm{Bt} \\
+\mathrm{Rt} ; \mathrm{M}_{2 \mathrm{R}}: \mathrm{St}+\mathrm{Ms}\end{array}$ & & $\begin{array}{l}\mathrm{M}_{2}: \text { Ky-in (R4) } \rightarrow \\
\text { St }+ \text { Chl-in (R5) }\end{array}$ \\
\hline
\end{tabular}

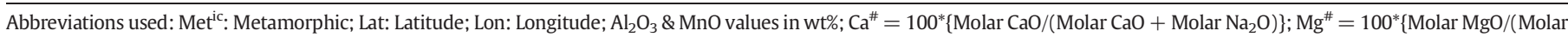

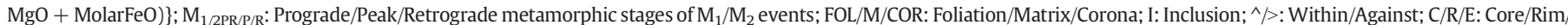

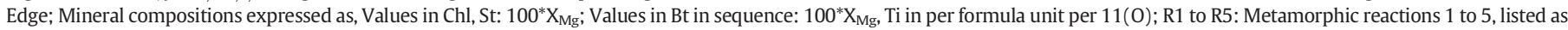

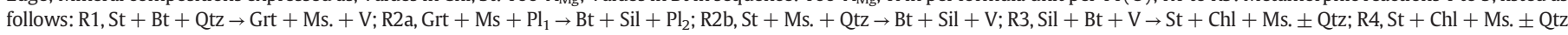
$\rightarrow \mathrm{Ky}+\mathrm{Bt}+\mathrm{V} ; \mathrm{R} 5, \mathrm{Ky}+\mathrm{Bt}+\mathrm{V} \rightarrow \mathrm{St}+\mathrm{Chl}+\mathrm{Ms} . \pm \mathrm{Qtz}$. 


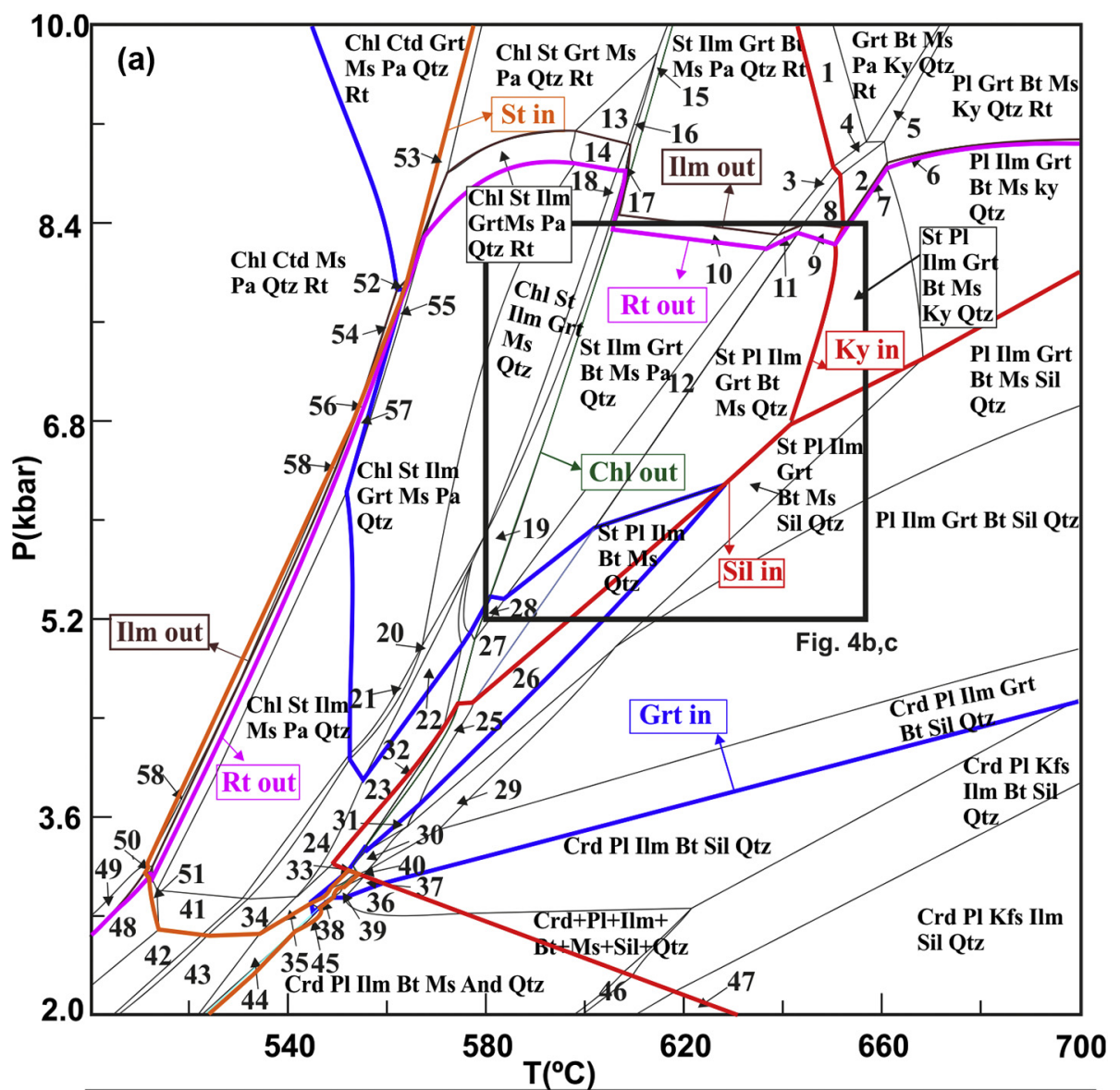

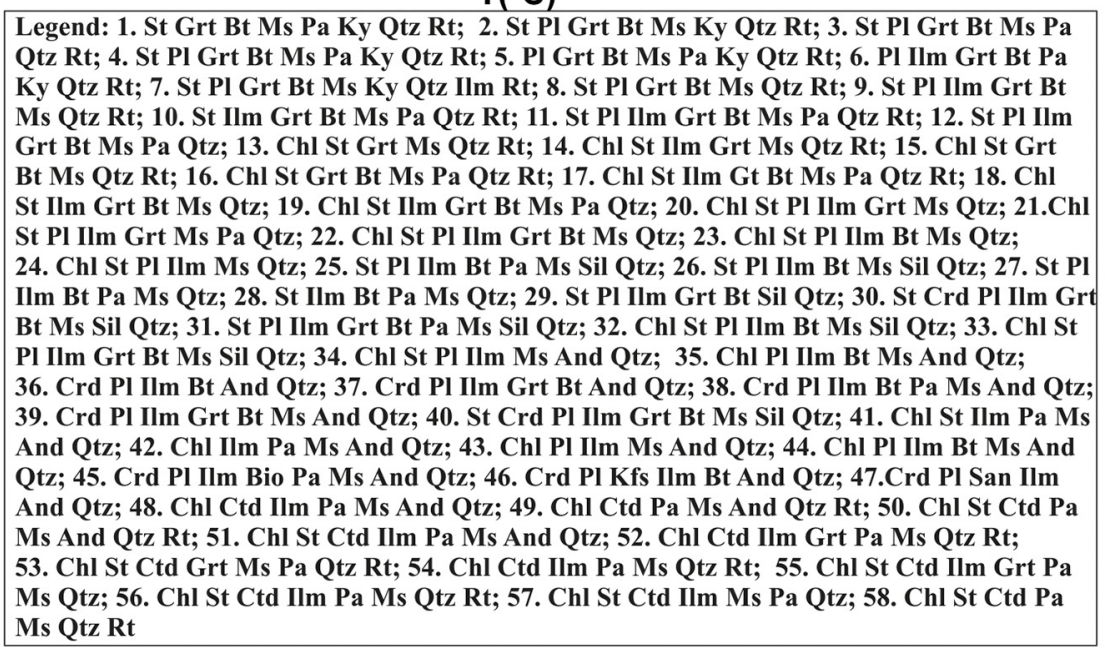

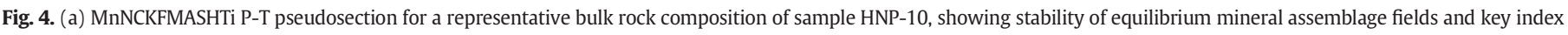

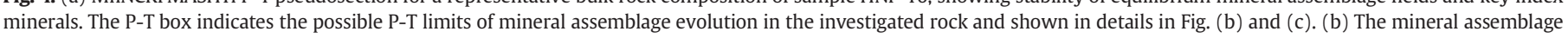

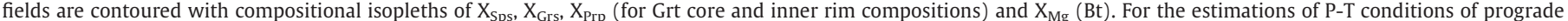

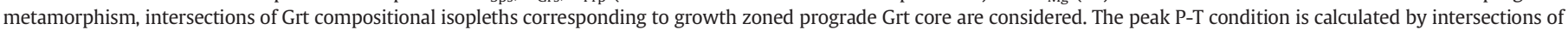

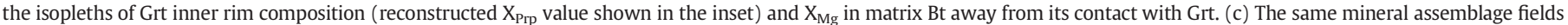

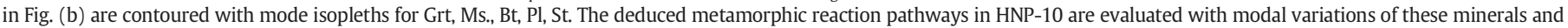
possible metamorphic P-T paths of evolution (see text for details).

Spot monazite ages yield Mesoarchaean dates with a range from 3246 to 3006 Ma (Supplementary Table S1; Fig. 5c, f, i).

$\mathrm{CD} 2$, which is recorded in both the samples occurs in several textural modes: (a) as thin rim around CD1 monazite (Fig. 5b-c, e-f), (b) as partial rim around CD1 monazite in a composite Mesoarchaean-Neoarchaean monazite grain (Fig. 5h-i), (c) as tiny relics within a Neoarchaean monazite (Fig. 5k-l) and (d) as an oval-shaped core, being surrounded by an overgrowth of Neoarchaean monazite. CD2 monazite as part of composite CD1-CD2 grains generally occur as inclusions in garnet and in matrix quartz (Fig. 5a,d). In contrast, relics of CD2 core in composite Mesoarchaean-Neoarchaean monazite grains occur in the foliation domain. Compositionally, the domain contains moderately high $\mathrm{Th}\left(\mathrm{ThO}_{2}\right.$ $=1.4-5.0 \mathrm{wt} \%)$, higher $\mathrm{Y}\left(\mathrm{Y}_{2} \mathrm{O}_{3}=1.4-1.9 \mathrm{wt} \%\right)$, moderate-high $\mathrm{U}\left(\mathrm{UO}_{2}\right.$ $=0.5-1.7 \mathrm{wt} \%$ ) contents (Supplementary Fig. S1) and very low $\mathrm{Th} / \mathrm{U}$ ratio (1-6) but relatively higher $\mathrm{X}_{\mathrm{YPO} 4}$ contents (Fig. 5o). Spot monazite 
(b)

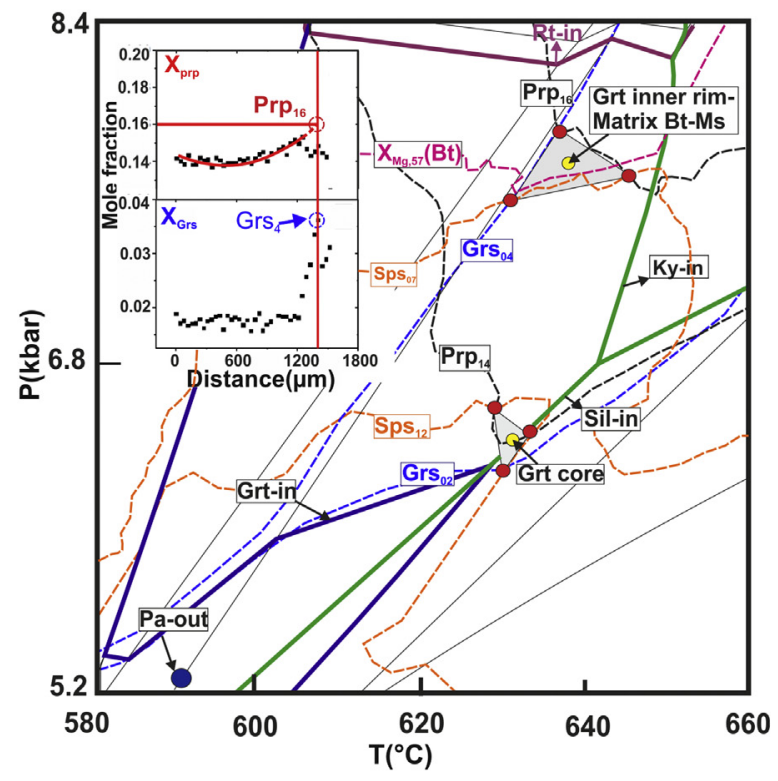

(c)

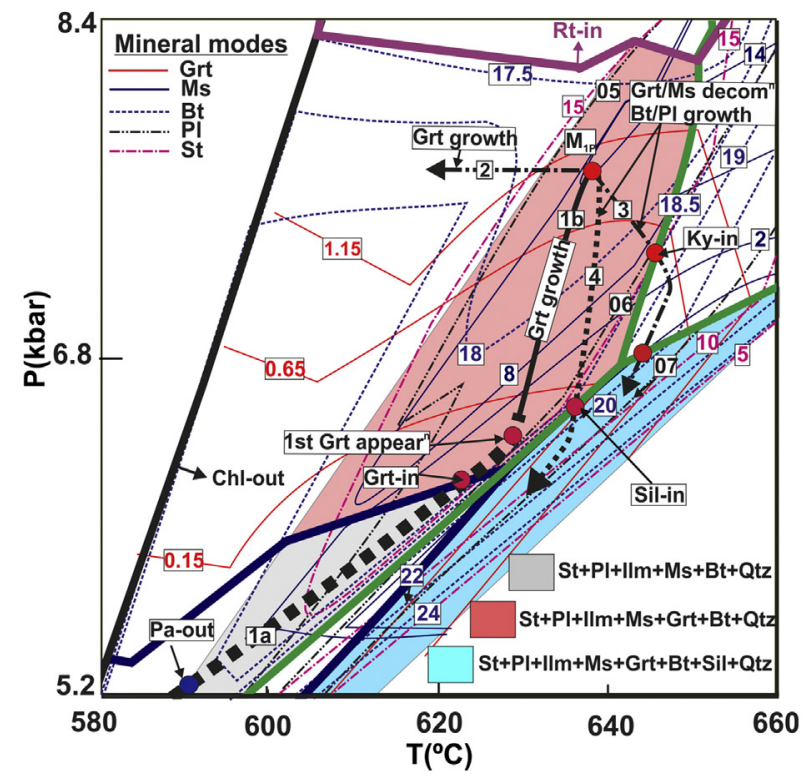

Fig. 4 (continued).

ages yield characteristic Mesoarchaean dates in the range: 32672902 Ma (Supplementary Table S1; Fig. 5c, f, i, 1).

The probability density diagrams for monazite spot ages from the two compositional domains and corresponding mean ages are shown in Fig. 6a-d. Both CD1 and CD2 domains exhibit a unimodal Mesoarchaean age population (Fig. 6a,c) with mean ages at $3120 \pm$ $28 \mathrm{Ma}$ (error 20, MSWD = 1.06, $\mathrm{n}=24$ ) (Fig. 6b) and $3094 \pm 24 \mathrm{Ma}$ (MSWD $=1.2, \mathrm{n}=21$ ) (Fig. $6 \mathrm{~d}$ ) respectively. While CD1 monazite core is texturally older, the age of the two domains cannot be distinguished within our analytical precision.

\section{SHRIMP U-Pb monazite dating}

The selected monazite grains from HNP-10 with known textural settings and compositional characteristics (e.g. compositional domains CD1 and CD2) are the ones whose chemical ages have been determined. This makes it possible to directly compare monazite EPMA and SHRIMP ages. Eight spots have been analysed in four monazite grains (numbering M1, M2, M5 and M7; Fig. 2a for textural locations and Fig. 7a-d for analytical spots in these monazite grains). All $\mathrm{U}-\mathrm{Pb}, \mathrm{Pb}-\mathrm{Pb}$ and $\mathrm{Th}-\mathrm{Pb}$ data are presented in Table 4 (see Supplementary Table S2 for the complete dataset).

The weighted mean ${ }^{207} \mathrm{~Pb} /{ }^{206} \mathrm{~Pb}$ age of all analyses shows excess scatter with an MSWD of 6.5. The analyses can be divided into two populations (P1 and P2) (Fig. 7e): P1 comprises the four analyses from sites M1-1, M5-2, and M5-3 that yield a ${ }^{204} \mathrm{~Pb} /{ }^{206} \mathrm{~Pb}$-corrected ${ }^{207} \mathrm{~Pb} /{ }^{206} \mathrm{~Pb}$ weighted mean age of $3144 \pm 7 \mathrm{Ma}(2 \sigma, \mathrm{MSWD}=0.74)$, while P2 comprises the four analyses from sites M2, M5-1, and M7 that yield a weighted mean age of $3105 \pm 10 \mathrm{Ma}(2 \sigma$, MSWD $=1.15)$.

Three of the ages from the older domain have been obtained from monazite grains occurring as inclusions in the inner rim of garnet (grain M1, Fig. 7a) or in matrix quartz from the interfolial domain (grain M5, Fig. 7b). While three of the ages are from the CD1 compositional domain (Fig. 7b), the remaining one is from an overlapping area between CD1 and CD2 (Fig. 7a). The four younger Mesoarchaean ages are obtained from monazite grains occurring as inclusions in the outermost rim of garnet (grain M2 with CD1 domain, Fig. 7c), in the foliation domain (CD1 in grain M7, Fig. 7d) and in interfolial quartz (overlapping CD1-CD2 in grain M5, Fig. 7b).

In terms of the $\mathrm{Pb} / \mathrm{U}$ and $\mathrm{Pb} / \mathrm{Th}$ chronometers, $\mathrm{P} 1$ has a ${ }^{204} \mathrm{~Pb} /{ }^{206} \mathrm{~Pb}$ corrected ${ }^{206} \mathrm{~Pb} /{ }^{238} \mathrm{U}$ age of $3270 \pm 110(\mathrm{MSWD}=0.65)$, and a ${ }^{208} \mathrm{~Pb} /{ }^{232} \mathrm{Th}$ age of $3290 \pm 80(\mathrm{MSWD}=2.6)$. For P2, the ${ }^{206} \mathrm{~Pb} /{ }^{238} \mathrm{U}$ age is $3200 \pm 100 \mathrm{Ma}(\mathrm{MSWD}=0.12)$, and the ${ }^{208} \mathrm{~Pb}^{/ 232} \mathrm{Th}$ age is $3190 \pm 80 \mathrm{Ma}(\mathrm{MSWD}=0.14)$. Thus a difference exists between the populations for both $\mathrm{Pb} / \mathrm{U}$ and $\mathrm{Pb} / \mathrm{Th}$ chronometers, but the uncertainties are larger and the age distinction is not as clear as that provided by the ${ }^{207} \mathrm{~Pb} /{ }^{206} \mathrm{~Pb}$ chronometry. While monazite has intrinsically high concentrations of $U$ and $T h$, and these monazites are old so also have high $\mathrm{Pb}$, the external reproducibility of monazite is apparently poorer for monazite than for zircon (Ireland and Gibson, 1998; Ireland and Williams, 2003). This may relate to matrix effects based on mineralogical composition (huttonite-monazite solid solution), crystal orientation effects, or chemistry of the constituent minerals.

In the Tera-Wasserburg concordia diagram (Fig. 7f), the monazite analyses range from concordant to slightly reversely discordant, that is, the ${ }^{206} \mathrm{~Pb} /{ }^{238} \mathrm{U}$ ages are generally greater than the ${ }^{207} \mathrm{~Pb} /{ }^{206} \mathrm{~Pb}$ ages. In this data set, the reverse discordance ranges between 1 and $7 \%$. Reverse discordance is generally attributed to two different causes - geological and analytical. Williams et al. (1984) first noted large degrees of reverse discordance in high temperature metamorphic zircons. Reverse discordance in Palaeoarchaean monazite has also been reported previously from the Barberton Granite-Greenstone Belt (Cutts et al., 2014). These cases of reverse discordance are related to $\mathrm{Pb}$ redistribution during metamorphism. For the monazite systematics described here, this appears to be unlikely because two discrete age groups are maintained in the monazites analysed, and early $\mathrm{Pb}$ redistribution should affect ${ }^{207} \mathrm{~Pb} /{ }^{206} \mathrm{~Pb}$ ages as well as $\mathrm{Pb} / \mathrm{U}$ ages. $\mathrm{U}$ loss or $\mathrm{Pb}$ gain caused by recent alteration (e.g. Rohr et al., 2004) has also been described. This is possible, but the uniformity of the offset would not necessarily be expected from this process, with $\mathrm{U}$ gain and $\mathrm{Pb}$ loss being the most common case. An additional geological cause, preferential incorporation of excess amount of ${ }^{230} \mathrm{Th}$, which decays to ${ }^{206} \mathrm{~Pb}$ (Parrish, 1990; Schärer, 1984), is not relevant here because it is only an issue in much younger monazites.

Analytical artefacts relate largely to inappropriate calibration of inter-element ratios because of matrix effects (Ireland, 1995), or to 

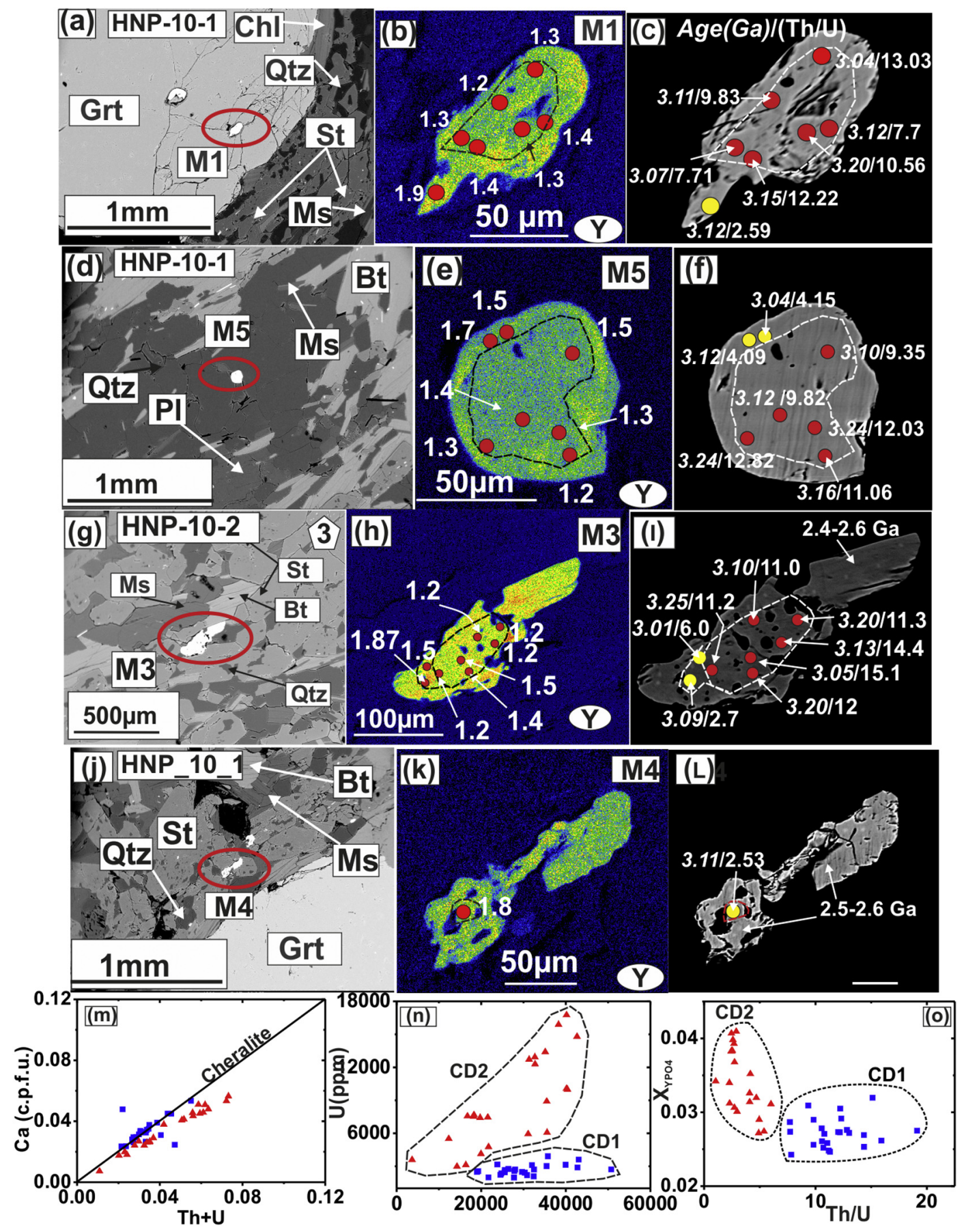

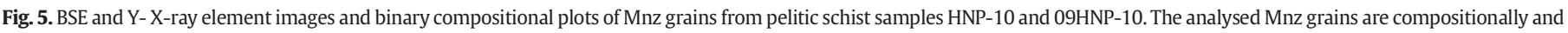

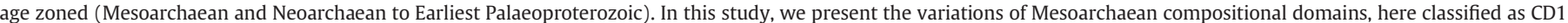

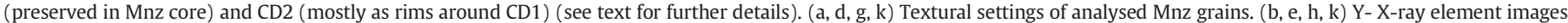

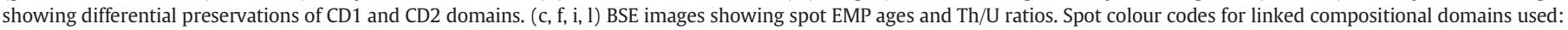

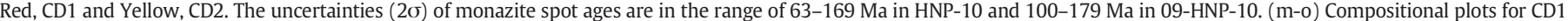
and $\mathrm{CD} 2$ compositional domains. (Th $+\mathrm{U})$ vs. $\mathrm{Ca}(\mathrm{m})$, Th $(\mathrm{ppm})$ vs. $\mathrm{U}(\mathrm{ppm})(\mathrm{n})$ and $\mathrm{X}_{\mathrm{YPO} 4} \mathrm{Vs}, \mathrm{Th} / \mathrm{U}(\mathrm{o})$ binary diagrams.

sample preparation. A bias from standard-sample matrix-mismatch (Fletcher et al., 2010; Hetherington et al., 2017; Stern and Berman, 2001) does not appear to be an issue here. Relevant instrumental indicators $\left(\mathrm{UO}^{+} / \mathrm{U}^{+}\right.$, secondary tuning parameters) were very similar between standards and unknowns. An analytical problem relating to sample preparation, i.e. the use of thin sections for the unknowns and epoxy casting for the standards is the most likely possibility, but even here there is no indication from instrumental conditions that this has caused a bias. Despite the issues with the detailed calibration of $\mathrm{Pb} / \mathrm{U}$ and $\mathrm{Pb} / \mathrm{Th}$, the ${ }^{207} \mathrm{~Pb} /{ }^{206} \mathrm{~Pb}$ ratio is immune to these issues and also provides better age resolution. The significance of these ages in a metamorphic context are further examined in the Discussion section.

\section{Garnet-monazite thermometry}

Textural and compositional features reveal that in a xenotimeabsent mineral assemblage as in the HGB, monazite core (cf. CD1 compositional domain) grew in the presence of a growth-zoned garnet inner rim at metamorphic peak. These are: (1) This compositional type is preferentially preserved in monazite shielded either in the 

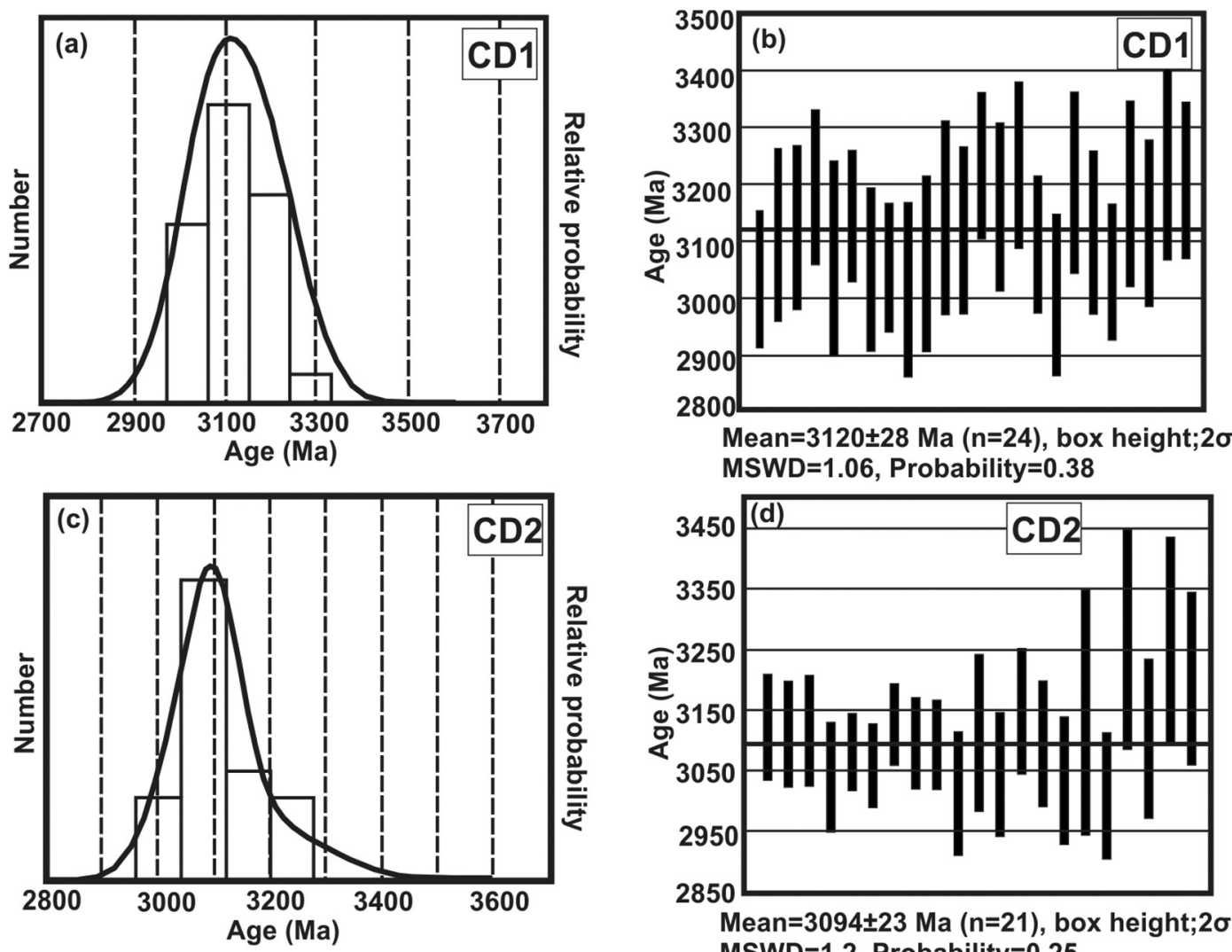

Mean=3094 $\pm 23 \mathrm{Ma}(\mathrm{n}=21)$, box height;2 $\sigma$ MSWD=1.2, Probability $=0.25$

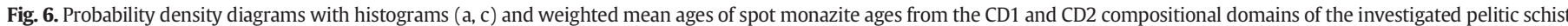
samples. All error bars are $2 \sigma$.
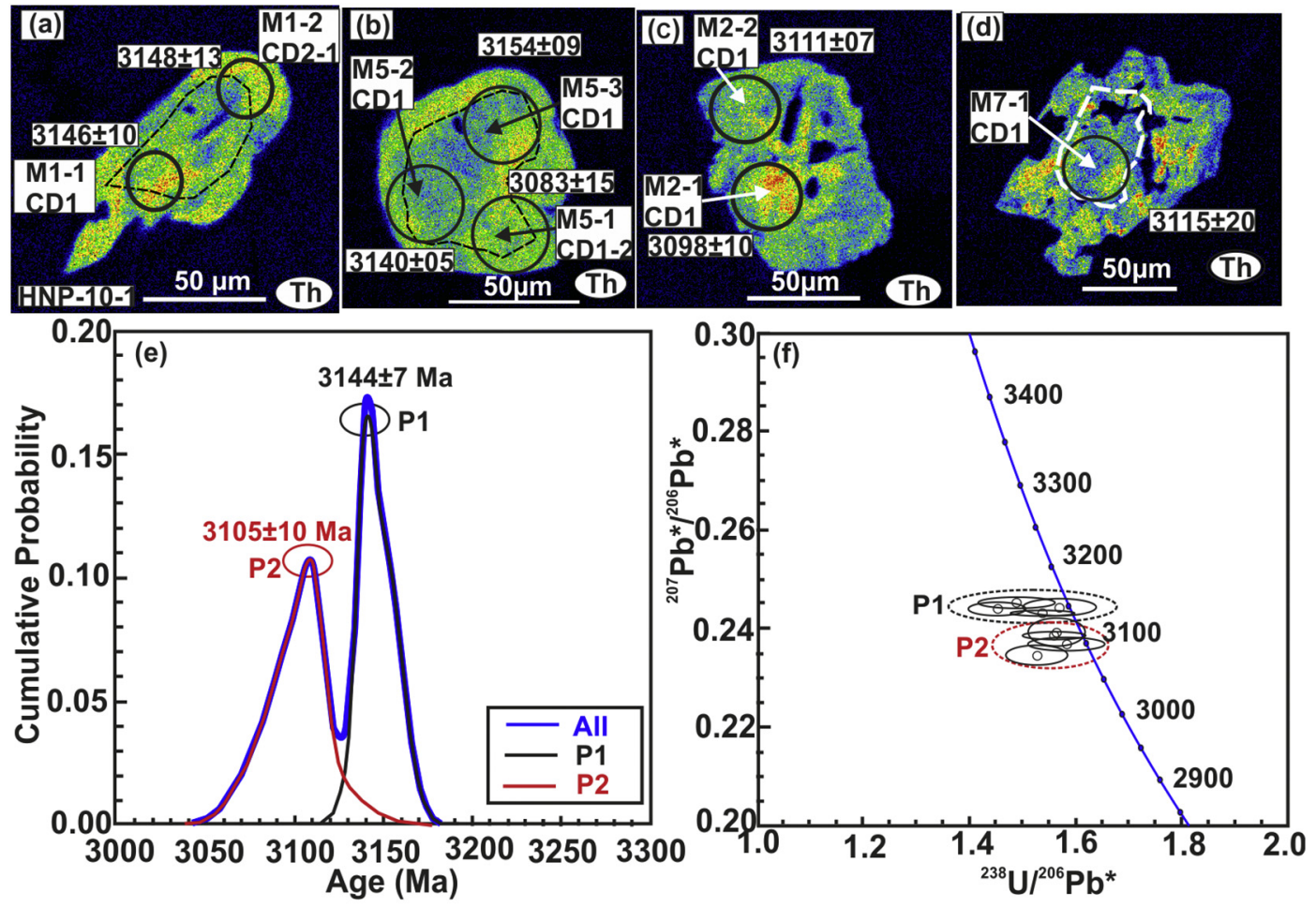

Fig.7

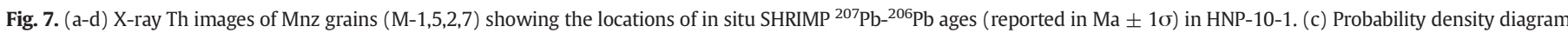

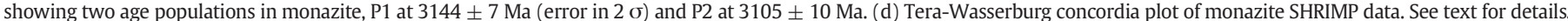


Table 4

SHRIMP monazite U-Pb isotope data in the pelitic schist sample HNP-10-1 from the Holenarsipur Greenstone Belt, WDC.

\begin{tabular}{|c|c|c|c|c|c|c|c|c|c|c|c|c|c|}
\hline Label & Th/U & $\begin{array}{l}{ }^{204} \mathrm{~Pb} /{ }^{206} \mathrm{~Pb} \\
(\mathrm{e}-5)\end{array}$ & $\begin{array}{l}\mathrm{f}_{206} \\
(\%)\end{array}$ & ${ }^{207} \mathrm{~Pb} /{ }^{206} \mathrm{~Pb}$ & ${ }^{208} \mathrm{~Pb} /{ }^{206} \mathrm{~Pb}$ & ${ }^{208} \mathrm{~Pb} /{ }^{232} \mathrm{Th}$ & ${ }^{206} \mathrm{~Pb} /{ }^{238} \mathrm{U}$ & ${ }^{207} \mathrm{~Pb} /{ }^{235} \mathrm{U}$ & ${ }^{238} \mathrm{U} /{ }^{206} \mathrm{~Pb}$ & $\begin{array}{l}\text { Age 8/32 } \\
\text { (Ma) }\end{array}$ & $\begin{array}{l}\text { Age 6/38 } \\
\text { (Ma) }\end{array}$ & $\begin{array}{l}\text { Age } 7 / 6 \\
\text { (Ma) }\end{array}$ & $\begin{array}{l}\% C \\
(\%)\end{array}$ \\
\hline M1-1 & 1 & 1.94 & .03 & 0.243 & 48 & 14 & 26 & 0.92 & 56 & 74 & 102 & 10 & 107 \\
\hline M1-2 & $4.39 \pm 0.49$ & 0.71 & 0.01 & $0.2442 \pm 19$ & $1.081 \pm 40$ & $0.1736 \pm 39$ & $0.637 \pm 29$ & $21.44 \pm 1.01$ & $1.570 \pm 71$ & $3236 \pm 67$ & $3177 \pm 115$ & $3148 \pm 13$ & 101 \\
\hline M2-1 & $18.1 \pm 3.2$ & 1.13 & 0.02 & $0.2368 \pm 15$ & $4.531 \pm 36$ & $0.1710 \pm 40$ & $0.631 \pm 30$ & $20.61 \pm 1.00$ & $1.584 \pm 75$ & $3190 \pm 69$ & $3154 \pm 119$ & $3098 \pm 10$ & 102 \\
\hline M2--2 & $4.61 \pm 0.34$ & 1.20 & 0.02 & $0.2386 \pm 10$ & $1.125 \pm 03$ & $0.1711 \pm 51$ & $0.641 \pm 25$ & $21.08 \pm 0.84$ & $1.560 \pm 61$ & $3193 \pm 89$ & $3193 \pm 100$ & $3111 \pm 07$ & 103 \\
\hline M5-1 & $5.16 \pm 0.26$ & 0.23 & 0.00 & $0.2346 \pm 22$ & $1.288 \pm 10$ & $0.1733 \pm 48$ & $0.654 \pm 26$ & $21.15 \pm 0.88$ & $1.529 \pm 60$ & $3230 \pm 83$ & 3244 & $3083 \pm 15$ & 105 \\
\hline M5-2 & $9.26 \pm 0.33$ & 0.56 & 0.01 & $0.2430 \pm 07$ & $2.264 \pm 22$ & $0.1701 \pm 47$ & $0.650 \pm 25$ & $21.78 \pm 0.88$ & $1.539 \pm 61$ & $3174 \pm 82$ & $3228 \pm 102$ & $3140 \pm 05$ & 103 \\
\hline M5-3 & $10.7 \pm 1.6$ & 0.12 & 0.00 & $0.2452 \pm 13$ & $2.628 \pm 23$ & $0.1773 \pm 43$ & $0.671 \pm 33$ & $22.69 \pm 1.17$ & $1.490 \pm 75$ & $3299 \pm 74$ & $3311 \pm 132$ & $3154 \pm 09$ & 105 \\
\hline M7-1 & $13.14 \pm 0.56$ & 2.94 & 0.05 & $0.2392 \pm 30$ & $3.226 \pm 24$ & $0.1688 \pm 50$ & $0.639 \pm 23$ & $21.09 \pm 0.82$ & $1.564 \pm 55$ & $3153 \pm 87$ & $3186 \pm 90$ & $3115 \pm 20$ & 102 \\
\hline
\end{tabular}

Abbreviations: $\mathrm{f}_{206}$ - fraction of common ${ }^{206} \mathrm{~Pb}$ in total $\mathrm{Pb}$; \% - Concordance (\%).

inner rim of garnet or in low-strain interfolial domain in the matrix. (2) Chondrite normalised REE plots show steep LREE enrichment and HREE depletion and a strong negative Eu anomaly (Fig. 8a), consistent with their growth in the presence of plagioclase as indicated by the reconstructed peak metamorphic assemblage. (3) Monazite cores showing relatively lower Y concentrations (Fig. 5o) and REE partitioning relationship between monazite and inner garnet rim, broadly in agreement with natural rock data (Fig. 8b) together reveal broadly co-eval crystallization of garnet and monazite (e.g. Hermann and Rubatto, 2003; Warren et al., 2018). We combine these compositional features of monazite and garnet with the composition of included apatite $\left(\mathrm{X}_{\mathrm{OH}}\right.$ $=0.06)$ in garnet and relatively sodic plagioclase composition $\left(\mathrm{X}_{\mathrm{An}}=\right.$ 0.11 to 0.15 ) either from its occurrence as inclusion within garnet or from matrix plagioclase core. The peak P-T conditions at which the fugacity of $\mathrm{H}_{2} \mathrm{O}$ was calculated were acquired from the results of pseudosection modelling. The selected mineral compositions [ $\mathrm{X}_{\mathrm{YAG}}$, $\mathrm{X}_{\mathrm{Grs}}, \mathrm{X}_{\mathrm{YPO} 4}(\mathrm{Mnz}), \mathrm{X}_{\mathrm{OH}}(\mathrm{Ap})$ and $\mathrm{X}_{\mathrm{An}}$ ] and calculated $\mathrm{f}_{\mathrm{H} 2 \mathrm{O}}$ value are listed in Table 5. Garnet-monazite thermometry has yielded temperatures of $605-610{ }^{\circ} \mathrm{C}$ (Table 5), in broad agreement with the estimated peak metamorphic temperature at $\sim 640^{\circ} \mathrm{C}$.

\section{Discussion}

9.1. Timing of monazite growth and recrystallization behavior in a metamorphic context

Our study indicates formation of two distinct types of Mesoarchaean monazite grains. Textural and compositional features and garnetmonazite thermometric results together suggest that the CD1 monazite core formed during peak $\mathrm{M}_{1}$ (cf. $\mathrm{M}_{1 \mathrm{P}}$ ) metamorphism (Fig. 9). Textural and compositional features of the occurrence of $\mathrm{CD} 2$ monazite rims around the core, outer boundary of the former often resembling the outline of the remnant core (e.g. monazite grains M1 and M5, Fig. 5a-f) and relatively sharp compositional variation (e.g. in $\mathrm{Y}$, Th and $\mathrm{U}$ ) across the domain boundary attest to the formation of the CD2 monazite via a mechanism of dissolution-reprecipitation of the CD1 monazite (cf. Bhowmik et al., 2014; Putnis, 2002). Their relatively higher Y contents and higher uranium and low $\mathrm{Th} / \mathrm{U}$ compositions relative to their core (Fig. 5n-0) when combined with Y and HREE enrichments in the outer rim of garnet (Fig. 3s-v) indicate that this metamorphic recrystallization event was associated with the coupled decompositions of garnet and a uranium-bearing phase, most likely zircon. On the basis of this evidence, we relate the CD2 monazite rim with the post-peak decompression ( $\mathrm{M}_{1 \mathrm{R}}$ metamorphic stage, where $\mathrm{R}$ refers to retrogression, Fig. 9).

Monazite Th-U-Pb EPMA ages have constrained the timings of development of monazite cores and rims at $3120 \pm 28 \mathrm{Ma}$ and $3094 \pm 24 \mathrm{Ma}$ respectively. Although, these ages are statistically the same within their error limits, they do provide a first order constraint on the timing of a Mesoarchaean metamorphic event between 3.12 and 3.09 Ga in the Holenarsipur Greenstone Belt. The higher precision of the SHRIMP ${ }^{207} \mathrm{~Pb}-{ }^{206} \mathrm{~Pb}$ monazite dating further resolves these events at $3144 \pm$ $7 \mathrm{Ma}$ and $3105 \pm 10 \mathrm{Ma}$. The older age domain is largely derived from monazite cores, which have been shielded from later equilibrations in garnet inner rim and interfolial matrix quartz. For this reason, we consider it as the timing of the $\mathrm{M}_{1 \mathrm{P}}$ metamorphism. For the younger monazite age domain, two of the analysed SHRIMP spots lie on monazite included in the outermost garnet rim. This part of the growth zoned garnet rim is compositionally modified due to its dissolution following peak metamorphism. The remaining two analyses of monazite are from the matrix. There are two possibilities to interpret the $3.11 \mathrm{Ga}$ monazite age domain: (a) a reset $\mathrm{M}_{1 \mathrm{p}}$ age due to modifications of isotopic compositions during the retrograde metamorphism, (b) a variation in $\mathrm{M}_{1 \mathrm{P}}$ age due to an initial compositional heterogeneity of the monazite core domain. Since there is a difference of $\sim 40$ Myrs in the two age populations, which is larger than the age uncertainty, we discount option
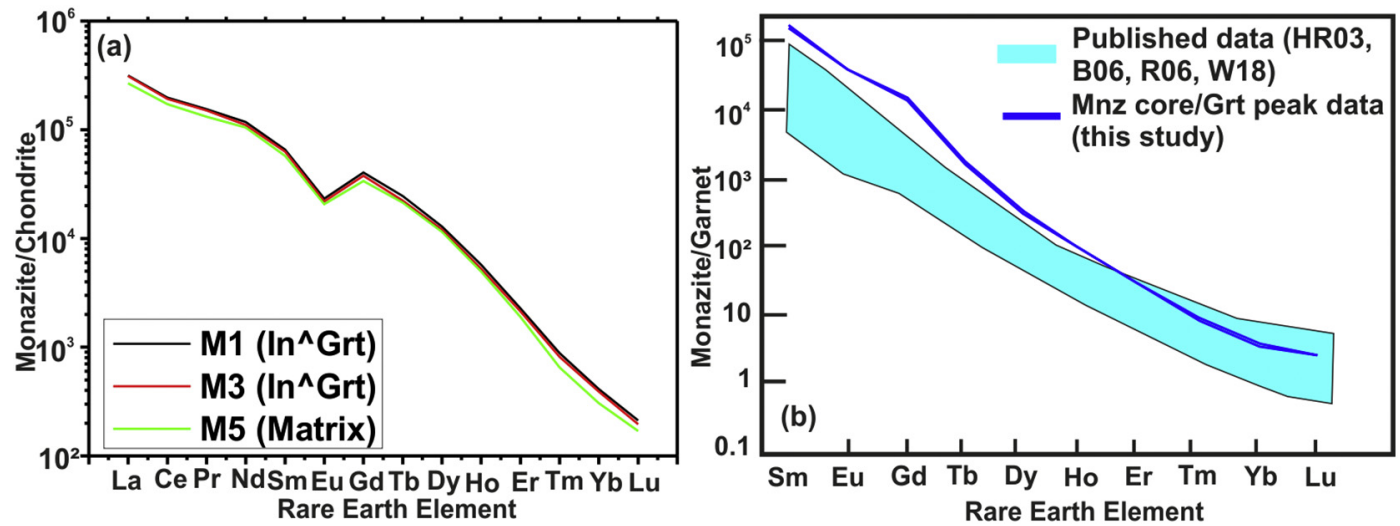

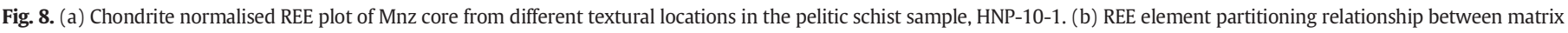

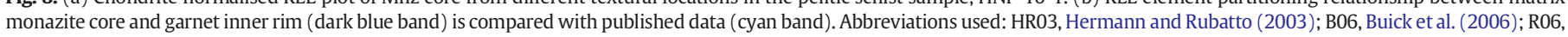
Rubatto et al. (2006); W18, Warren et al. (2018). 
Table 5

Results of garnet-monazite thermometry in sample HNP-10-1.

\begin{tabular}{ll}
\hline Input parameters & Values \\
\hline $\mathrm{X}_{\mathrm{Grs}}$ & 0.04 \\
$\mathrm{X}_{\mathrm{YAG}}$ & 0.00015 \\
$\mathrm{X}_{\mathrm{An}}$ & $0.11-0.15$ \\
$\mathrm{X}_{\mathrm{YPO} 4}$ & 0.03 \\
$\mathrm{X}_{\mathrm{OH}, \mathrm{Ap}}$ & 0.06 \\
$\mathrm{f}\left(\mathrm{H}_{2} \mathrm{O}\right)$ & 6623.6 \\
$\mathrm{Ln}\left(\mathrm{K}_{\mathrm{Eq}}\right)$ & $8.278-8.665$ \\
$\mathrm{~T}_{\mathrm{Calc}}\left({ }^{\circ} \mathrm{C}\right)$ & $605-610$ \\
Textural settings & $\mathrm{Grt}(\mathrm{IR}), \mathrm{Mnz}(\mathrm{C}), \mathrm{Ap}\left(\mathrm{I}^{\wedge} \mathrm{Grt}\right), \mathrm{Pl}\left(\mathrm{I}^{\wedge} \mathrm{Grt}, \mathrm{M}(\mathrm{C})\right)$ \\
\hline
\end{tabular}

Textural abbreviations as in Table 1; Mineral mole fraction data computed after Pyle et al. (2001).

(b). Based on this analysis, we consider the best estimate of the peak $\mathrm{M}_{1}$ metamorphism in the Holenarsipur Greenstone Belt is 3.14 Ga with the subsequent decompression recorded at $3.11 \mathrm{Ga}$.

In a previous study, Bouhallier (1995) established a Neoarchaean to Earliest Palaeoproterozoic metamorphism in the HGB on the basis of garnet Sm-Nd ages $(2473 \pm 10 \mathrm{Ma}$ to $2527 \pm 34 \mathrm{Ma})$ in two pelitic schist samples (quoted in Jayananda et al., 2013), which are also recorded in our investigated pelitic schist samples. Published garnet SmNd (Bouhallier, 1995; Li et al., 2018) and U-Pb zircon (Li et al., 2018) ages in the high-grade Sargur supracrustals and U-Pb zircon ages in granulite facies crustal blocks adjoining the Dharwar Craton (e.g. Brandt et al., 2014) also indicate that vast stretches of the Western Dharwar Craton and also the adjoining Southern Granulite Terrane have recorded a pervasive tectonothermal event in Neoarchaean to Earliest Palaeoproterozoic time that reached high-pressure granulite facies in the south. Our study reveals that despite a veil of a strong amphibolite facies kyanite-zone metamorphic overprint, an earlier Mesoarchaean metamorphism between 3.14 and $3.11 \mathrm{Ga}$ can still be recognised in localised domains of the HGB. While several previous studies inferred Mesoarchaean metamorphism in the WDC (Jayananda et al., 2013, 2015; Raith et al., 1982), this is the first comprehensive documentation of the event in the terrane, including reconstruction of the metamorphic P-T path.

\subsection{Mesoarchaean metamorphic P-T Path and geodynamic significance}

The reconstructed CW metamorphic P-T path in the HGB reveals a two-stage prograde evolution ( $\mathrm{M}_{1 \mathrm{PR}}$ metamorphic stage): an initial phase of heating accompanying burial along a relatively gentle $\mathrm{dP} / \mathrm{dT}$ gradient $\left(\sim 30 \mathrm{bar} /{ }^{\circ} \mathrm{C}\right)$ followed by burial $(\Delta \mathrm{P} \sim 1.1 \mathrm{kbar})$ along a steep $\mathrm{dP} / \mathrm{dT}$ gradient $\left(\sim 110 \mathrm{bar} /{ }^{\circ} \mathrm{C}\right)$, culminating in peak metamorphism $\left(\mathrm{M}_{1 \mathrm{P}}\right)$ at $7.5 \mathrm{kbar}, 640{ }^{\circ} \mathrm{C}$ (Fig. 9). In a general way, such a change in $\mathrm{dP} / \mathrm{dT}$ gradient reflects a change in burial mechanism from one in which the underthrusted or buried Holenarsipur Greenstone Crust equilibrated with relatively warmer footwall and hanging wall rocks to one of extremely rapid burial. The retrograde isothermal decompression path ( $\mathrm{M}_{1 \mathrm{R}}$ stage) which broadly retraces the steep prograde burial path, but at higher temperatures also implies a very short-lived residence at metamorphic peak and a very fast tectonically-driven exhumation. Although such a hair-pin P-T path, reflecting a very rapid burial and exhumation cycle, is indicative of a subduction zone metamorphic setting, particularly in Phaneozoic metamorphic belts (e.g. Agard et al., 2009; Ao and Bhowmik, 2014; Ernst, 1988), the application of the same in Archaean granite-greenstone terrane is controversial (e.g. see Sizova et al., 2018 for a review).

In the Palaeo- to Mesoarchaean Barberton Granite-Greenstone Terrane (BGGT), several studies have recorded high-pressure $\left(\mathrm{P}_{\mathrm{Max}}\right.$ from $\sim 8.5$ to 12 kbar) amphibolite facies metamorphism along clockwise metamorphic P-T paths at ca. $3200 \mathrm{Ma}$ (Fig. 9) and an oblique crustal section in the Slotzberg terrane (Cutts et al., 2014; Diener et al., 2005; Dziggel et al., 2002; Moyen et al., 2006). This has been explained by a model of crustal thickening due to an accretionary tectonic process
(Cutts et al., 2014 and references cited therein). Several recent studies, involving thermo-mechanical modelling (e.g. Sizova et al., 2015, 2018) with or without integrated metamorphic and geochronological constraints of natural rock data (e.g. François et al., 2014), however, suggest that burial-exhumation cycles along clockwise P-T loops (e.g. Fig. 10) are not diagnostic of subduction-accretion tectonics. These can also be explained by vertical tectonics akin to sagduction settings (terminology Macgregor, 1951) (e.g. in ca. 3.5-3.2 Ga high-grade Mount Edgar highgrade metamorphic rocks in the East Pilbara Granite-Greenstone Terrane, EPGGT, François et al., 2014; BGGT, Van Kranendonk, 2011b, Van Kranendonk et al., 2014).

In this model, spatial association of Archaean granitoid domes and intervening volcano-sedimentary basins, now represented by greenstone terranes and metamorphic transformations in greenstone protoliths are explained by a co-eval process of gravitational sinking of dense greenstone cover sequences into narrow belts and emplacement of partially melted felsic crust into broad granitoid domes (François et al., 2014; Sizova et al., 2018). The model predicts a wide diversity of metamorphic P-T paths and peak P-T conditions of greenstone metamorphism depending on their spatial positions vis-à-vis the granitoid domes e.g. greenstone margin, greenstone interior and greenstone enclaves within the granitoids, (summarised in Fig. 10a-c). The model also calculates a large range of apparent thermal gradients, including significantly lower gradients (ca. $15{ }^{\circ} \mathrm{C} / \mathrm{km}$ ) (François et al., 2014), akin to those proposed for modern and Archaean subductionaccretion zones (e.g. Moyen et al., 2006). Thus in the EPGGT, adjoining Mount Edgar dome, greenstone enclaves in the dome interior (sample PB-11-23, Fig. 9) were extensively heated at shallow to mid-crustal levels to produce metatexite migmatite (see also Fig. 10c for thermomechanical model prediction). In contrast, rocks in the greenstone interior (e.g. samples PB-11-35 and 33, Fig. 9) were progressively cooler away from their contact with the granitoid dome (Fig. 10b). Some of the rocks from the margin were also buried to a deeper level (sample No. PB-11-23, Figs. 9, 10a). While these thermo-mechanical models with initial conditions appropriate for vertical tectonics in Eoarchaean to Mesoarchaean time period, reproduce geometry of metamorphic PT paths (e.g. Sizova et al., 2018) that have been obtained from natural rock data (e.g. Fig. 9), one key distinction of sagduction from subduction is that the former is a mechanically short-lived process. The burial and exhumation cycle of the greenstone crust in sagduction is broadly

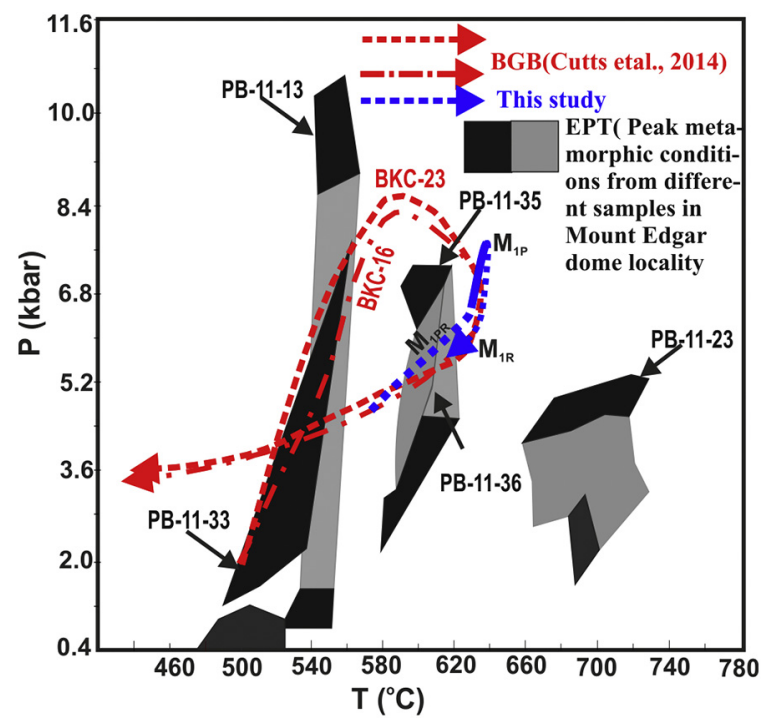

Fig. 9. P-T diagram showing a comparison between the P-T path from this study and published Mesoarchaean P-T paths and peak metamorphic conditions from two well studied greenstone belts, namely the Barberton Greensone Belt (BGB) and East Pilbara Granite-Greenstone Terrane (EPT). 
synchronous with peak magmatic activities (François et al., 2014). This is followed by protracted slow thermal relaxation periods.

\subsection{Mesoarchaean tectonics in the Western Dharwar Craton}

The pelitic schist lies at the interface between the Holenarsipur Greenstone Belt and the Halekote trondhjemite pluton (Fig. 1b). The latter was emplaced into the supracrustal sequence as a diapiric body (Bouhallier et al., 1995). While Bouhallier et al. (1995) applied field observations and structural criteria to propose a sagduction model for the evolution of the Holenarsipur Greenstone Belt, which has been widely accepted since then as a general geodynamic model in the Mesoarchaean, it was never independently validated by co-eval metamorphic age constraints from the sagducted greenstones. The metamorphic and chronological constraints in this study help to resolve this issue.

A collation of published zircon and titanite $\mathrm{U}-\mathrm{Pb}$ geochronological data of felsic magmatic bodies reveal three periods of magmatism in the terrane (Fig. 11): (1) between 3411 and $3276 \mathrm{Ma}$ (Beckinsale et al., 1980, 1982; Bhaskar Rao et al., 2008; Guitreau et al., 2017; Jayananda et al., 2015; Peucat et al., 1993; Santosh and Li, 2018) marking the main phase of growth of the Garur and Eastern TTG gneisses, (2) between 3230 and 3200 Ma (Jayananda et al., 2015) with a precise time constraint of $\sim 3178 \mathrm{Ma}$ as the timing of emplacement of Halekote and equivalent trondhjemitic pluton (Guitreau et al., 2017) and (3) between 3134 and $3103 \mathrm{Ma}$ as a minor phase of granite intrusion in the Garur gneiss (Guitreau et al., 2017; Jayananda et al., 2015). Published U-Pb detrital and inherited zircon ages and $\mathrm{Nd}-\mathrm{Hf}-\mathrm{Pb}$ isotope data additionally indicate a cryptic record of an even older phase of crust formation in the WDC dating back to 3.8 Ga (Bhaskar Rao et al., 2008; Guitreau et al., 2017; Hokada et al., 2013; Jayananda et al., 2015; Lancaster et al., 2015; Nutman et al., 1992; Sarma et al., 2012).

On the basis of $\mathrm{Hf}$ isotopic fingerprinting of detrital zircons, Guitreau et al. (2017) related these crust-formation events in the WDC with specific crust/mantle reservoirs: (a) Pre-3400 Ma crust sourced from several distinct mantle domains with ancient depletion history. (b) 3400$3200 \mathrm{Ma}$ felsic crust originating from a common mantle source of mildly-depleted to near-chondritic Hf isotopic compositions with limited or no continental influence. (c) Magmatic events from $3200 \mathrm{Ma}$ onwards with signatures of reworked oldest WDC crust and also of dominant lithologies. This shift in isotopic reservoirs from predominantly mantle to continental types when evaluated with theoretical results, thermo-mechanical model predictions (François et al., 2014; Sizova et al., 2015, 2018) and natural rock data (e.g. Jayananda et al., 2008, 2015; Guitreau et al., 2017 and this study) suggests a change in the style of Mesoarchaean tectonics in the WDC from ca. $3.2 \mathrm{Ga}$ onwards.

While there are suggestions that subduction tectonics may have led to the growth of TTG crust in the Gorur-Holenarsipur region (e.g. Jayananda et al., 2015; Naqvi et al., 2009), the overall geological setting and geochemical framework of the terrane [e.g. Sargur komatiite eruption as part of a plume-driven oceanic plateau formation event (e.g. Jayananda et al., 2008)] and spatial association of Holenarsipur Greenstone keel and Halekote diapirs (e.g. Bouhallier et al., 1995) are
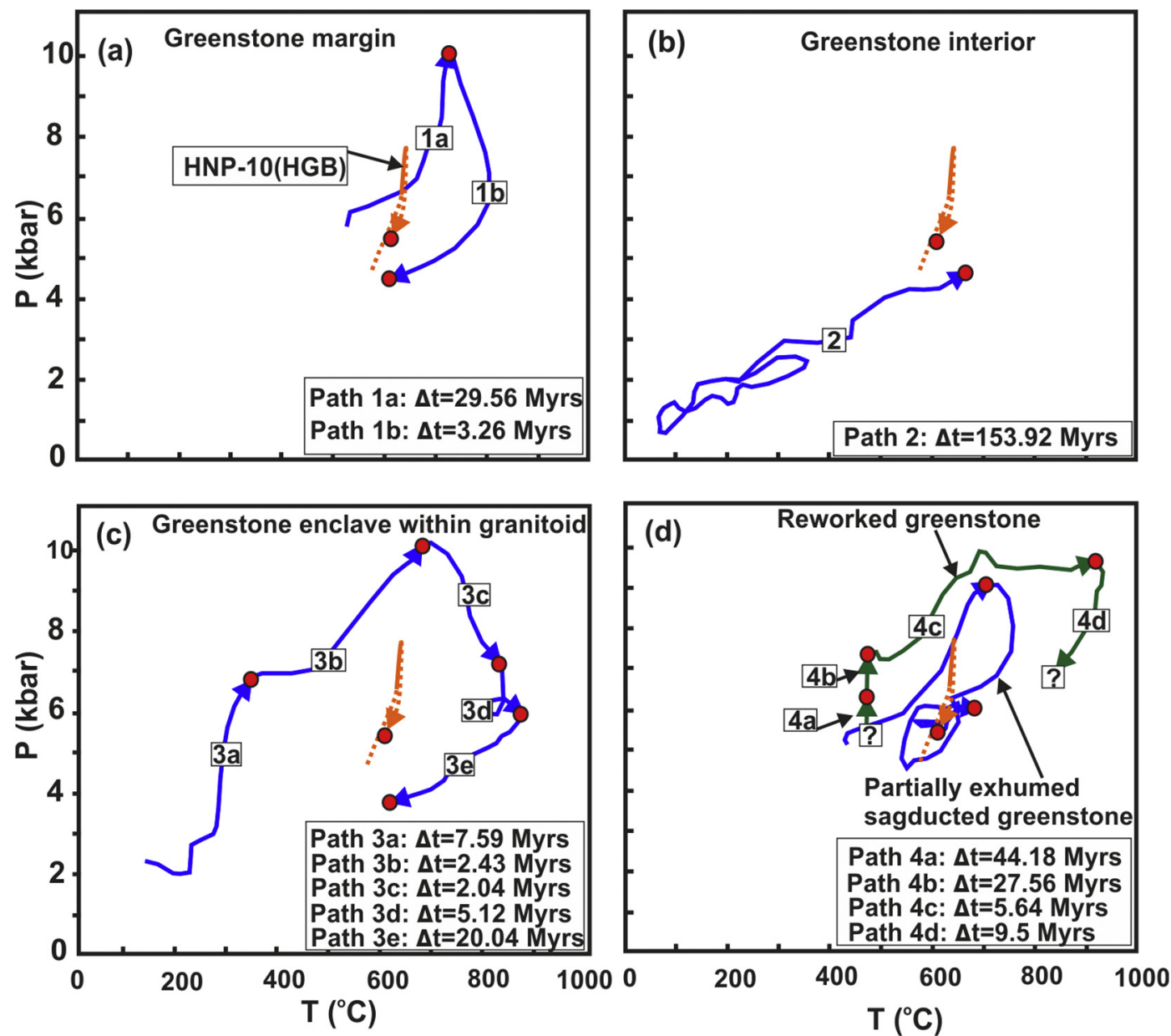

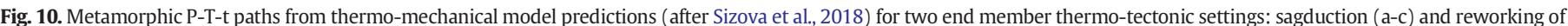

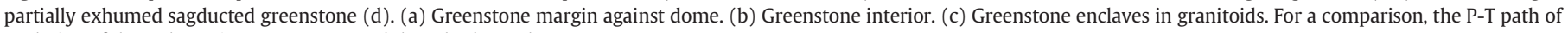
evolution of the Holenarsipur Greenstone Belt has also been shown. 


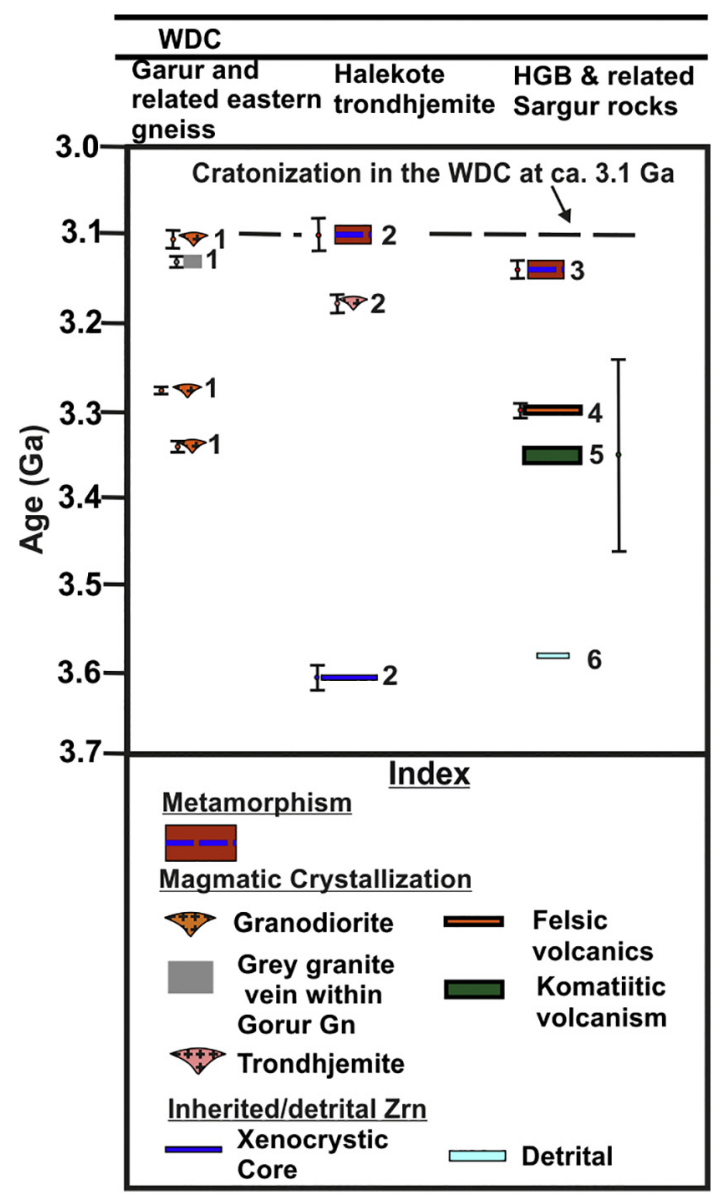

Fig. 11. A summary diagram showing a comparison of Mesoarchaean magmatic and metamorphic events in different litho-tectonic domains of the WDC. The numbers in the figure represent references: 1, Jayananda et al. (2015); 3, This study; 4, Peucat et al. (1995); 5, Jayananda et al. (2008), 6, Nutman et al. (1992).

supportive of a model of gravity-driven vertical tectonics in a time frame between 3.4 and 3.2. Seen in that context, despite the remarkable similarity of the Holenarsipur Greenstone P-T path with that from sagduction model simulation (Fig. 10a), the estimated peak greenstone metamorphism (this study) is younger in time than the diapiric plutonism by $\geq 35$ Myrs, but broadly coincident with metamorphism in associated TTG gneisses and Halekote diapir (Fig. 11). The metamorphism locally has resulted in crustal anatexis and granite vein formation (Jayananda et al., 2015). This raises the possibility that the tectonics responsible for the rapid burial and exhumation of a segment of the Holenarsipur Greenstone also reworked host TTG gneisses and diapirs. As stated above, thermo-mechanical models also predict formation of reworked (accreted) crust of strongly deformed and poly-phase metamorphosed (Fig. 10d) granite-greenstone and subduction-related sequences at later stages of sagduction tectonics as it evolves from predominantly vertical to horizontal shortening modes (e.g. Sizova et al., 2015, 2018). While the inferred model and reconstructed P-T paths and peak P-T estimates differ, in part due to chosen model physical parameters, this inference of a tectonic transition is also consistent with zircon Hf isotopic studies that reveal contributions of reworked older crust in the generations of post $3.2 \mathrm{Ga}$ felsic crust in the WDC (Guitreau et al., 2017). On the basis of these arguments, we propose that this first comprehensive record of ca. 3.14-3.11 Ga Mesoarchaean metamorphism in the HGB is part of a pervasive tectono-thermal event during late stages of sagduction tectonics. The event has led to large-scale cratonization of the WDC. Future studies should be directed to constrain the metamorphic and tectonic framework of this Mesoarchaen tectonothermal event from different litho-tectonic elements of the Western Dharwar Craton.

\section{Conclusions}

1. Rare high-alumina pelitic schists from the ca. 3.3-3.1 Ga HGB in the WDC, South India record a near complete preservation of an older Mesoarchaean metamorphic history, despite a strong superposed metamorphic overprint in the latest Neoarchaean to earliest Palaeoproterozoic time period.

2. The older history, now protected in low-strain domains of these rocks reveals three distinct metamorphic stages, which in a sequence are: (a) a partially preserved prograde heating stage, which is indicated by an early stability of chlorite $\left(\mathrm{X}_{\mathrm{Mg}}=0.50\right)$, biotite $\left(\mathrm{X}_{\mathrm{Mg}}=0.58-0.60\right)$ and paragonite $\left(\mathrm{Pa}_{62-68} \mathrm{Cel}_{11-12} \mathrm{Ms}_{09}\right.$ $\left.{ }_{15} \mathrm{Prl}_{07-17}\right)$ and formation of growth-zoned garnet $\left[\mathrm{Sps}_{12} \mathrm{Grs}_{02} \operatorname{Prp}_{14} \mathrm{Alm}_{72}\right.$ (Core) $\rightarrow \mathrm{Sps}_{07} \mathrm{Grs}_{04} \operatorname{Prp}_{16} \mathrm{Alm}_{73}$ (Rim)], (b) the peak metamorphism, which is represented by an assemblage of garnet + staurolite $\left(\mathrm{X}_{\mathrm{Mg}}=0.20\right)+$ ilmenite + muscovite $\left(\mathrm{Pa}_{26-29} \mathrm{Cel}_{8-11} \mathrm{Ms}_{58-63} \mathrm{Prl}_{2-4}\right)+$ biotite $\left(\mathrm{X}_{\mathrm{Mg}}=0.57-0.59\right)$ + sodic plagioclase $\left(\mathrm{An}_{11}\right.$ to $\left.\mathrm{An}_{15-16}\right)+$ quartz, and (c) the retrograde metamorphism, which is marked by the decomposition of garnet and formation of biotite $\left(\mathrm{X}_{\mathrm{Mg}}=0.56-0.57\right)$, fibrolitic sillimanite and calcic plagioclase $\left(\mathrm{An}_{21-22}\right)$.

3. On the basis of P-T pseudosection modelling in the MnTiNCKFMASH chemical system, we interpret the three metamorphic stages in terms of a hairpin clockwise P-T trajectory. The trajectory shows a two-stage prograde segment with an initial phase of heating accompanying burial $\left(\mathrm{dP} / \mathrm{dT}\right.$ gradient $\left.~ 30 \mathrm{bar} /{ }^{\circ} \mathrm{C}\right)$ and a later phase of steep burial $\left(\Delta \mathrm{P} \sim 1.1 \mathrm{kbar}, \mathrm{dP} / \mathrm{dT}\right.$ gradient $\left.\sim 110 \mathrm{bar} /{ }^{\circ} \mathrm{C}\right)$, peak metamorphism at $7.5 \mathrm{kbar}, 640{ }^{\circ} \mathrm{C}$ and a post-peak, steep decompression stage (P 6.3 kbar at $\left.635^{\circ} \mathrm{C}\right)$.

4. Chemically zoned monazite grains shielded within garnet or occurring in low-strain matrix domains attest to two stages of crystallization history during the Mesoarchaean metamorphism: (a) Monazite cores with relatively lower $Y$ concentrations, higher $\mathrm{Th} / \mathrm{U}$ ratios and a strong negative Eu anomaly crystallized in the presence of a growthzoned garnet inner rim at metamorphic peak. This interpretation is additionally supported by the application of garnet-monazite trace element thermometry. The combinations of monazite core $\left(\mathrm{X}_{\mathrm{YPO} 4}\right.$ $=0.03)$, garnet inner $\operatorname{rim}\left(\mathrm{X}_{\mathrm{Grs}}=0.04 ; \mathrm{X}_{\mathrm{YAG}}=0.00015\right)$, included apatite $\left(\mathrm{X}_{\mathrm{OH}}=0.06\right)$ in garnet and relatively sodic plagioclase composition $\left(\mathrm{X}_{\mathrm{An}}=0.11\right.$ to 0.15 ) have yielded temperatures of 605 $610{ }^{\circ} \mathrm{C}$, in broad agreement with the estimated peak metamorphic temperature at $\sim 640{ }^{\circ} \mathrm{C}$. (b) Monazite rims with higher $\mathrm{Y}$ and uraniferous compositions and lower Th/U ratios formed during the post-peak decompression stage associated with coupled decompositions of garnet and zircon.

5. The EPMA monazite dating has yielded mean core ages at $3120 \pm$ $28 \mathrm{Ma}$ and rim ages at $3094 \pm 24 \mathrm{Ma}$. Although, these ages are statistically the same within their error limits, they do provide a first order constraint on the timing of a Mesoarchaean metamorphic event between 3.12 and 3.09 Ga in the HGB.

6. The SHRIMP ${ }^{207} \mathrm{~Pb}-{ }^{206} \mathrm{~Pb}$ monazite dating method has yielded monazite core and rim ages at $3144 \pm 7 \mathrm{Ma}$ and $3105 \pm 10 \mathrm{Ma}$ respectively. The higher precision of the SHRIMP monazite ages allows resolution of the timings of peak and retrograde metamorphism in the terrane at 3.14 and 3.11 Ga respectively.

7. Our findings, when evaluated with the available geological, isotopic, geochronological data of Meso- to Palaeoarchaean felsic crust as well as thermo-mechanical models suggest that the Mesoarchaean metamorphism is part of a widespread tectonothermal event in the Western Dharwar Craton. The event marks a shift in tectonic style from initial sagduction to later horizontal plate motions. 
Supplementary data to this article can be found online at https://doi. org/10.1016/j.lithos.2019.06.006.

\section{Acknowledgement}

The paper constitutes a part of the doctoral thesis work of AD for which he acknowledges funding from the Indian Institute of Technology Kharagpur (IIT KGP) for an Institute doctoral fellowship and to carry out geological fieldwork. SKB acknowledges financial support from the IIT KGP in the form of a Cumulative Professional Development Allowance to undertake geological fieldwork and analytical work. SKB additionally acknowledges Prof. G.L. Clarke, University of Sydney for partially funding his visit to the Australian National University to undertake SHRIMP analytical work. SD acknowledges M. Jayananda for introducing him to the Dharwar geology and field support. We acknowledge help by D. Upadhyay, S. Ranjan and A. Banerjee with LA-ICPMS analysis and S. Basak with XRF analysis. Suggestions by S. Chakraborty on metamorphism and Archaean tectonics and by V. Ravikant on some aspects of geochronology have helped us to improve the paper. We thank P. Sengupta, M.E. Bickford and an anonymous reviewer for detailed reviews, and Marco Scambelluri for editorial handling. The paper is a contribution towards Schwerpunkt program (Priority Program) "Building a Habitable Earth" funded by the German Science Foundation (DFG).

\section{References}

Agard, P., Yamato, P., Jolivet, L., Burov, E., 2009. Exhumation of oceanic blueschists and eclogites in subduction zones: timing and mechanisms. Earth Sci. Rev. 92 (1-2), 53-79.

Ao, A., Bhowmik, S.K., 2014. Cold subduction of the Neotethys: the metamorphic record from finely banded lawsonite and epidote blueschists and associated metabasalts of the Nagaland Ophiolite Complex, India. J. Metamorph. Geol. 32 (8), 829-860.

Beckinsale, R.D., Drury, S.A., Holt, R.W., 1980. 3,360-Myr old gneisses from theSouth Indian Craton. Nature 283 (5746), 469-470.

Beckinsale, R.D., Reeves-Smith, G., Gale, N.H., Holt, R.W., Thompson, B., 1982. Rb-Sr and $\mathrm{Pb}-\mathrm{Pb}$ Whole Rock Isochron Ages and REE Data for Archaean Gneisses and Granites, Karnataka State, South India. INDO-US Workship on Precambrian of South India, pp. 35-36.

Bhaskar Rao, Y.J., Beck, W., Rama Murthy, V., Nirmal Charan, S., Naqvi, S.M., 1983. Geology, geochemistry and age of metamorphism of Archaean grey gneisses around Channarayapatna, Hassan district, Karnataka, South India. Precambrian of South India. Geol. Soc. India Mem. 4, 309-328.

Bhaskar Rao, Y.J., Griffin, W.L., Ketchum, J., Pearson, N.J., Beyer, E., O'Reilly, S.Y., 2008. An outline of juvenile crust formation and recycling history in the ArchaeanWestern Dharwar craton, from zircon in situ U-Pb dating and Hf-isotopiccompositions. Geochim. Cosmochim. Acta 72, A81.

Bhowmik, S.K., Wilde, S.A., Bhandari, A., Pal, T., Pant, N.C., 2012. Growth of the Greater Indian Landmass and its assembly in Rodinia: geochronological evidence from the Central Indian Tectonic Zone. Gondwana Res. 22 (1), 54-72.

Bhowmik, S.K., Wilde, S.A., Bhandari, A., Basu Sarbadhikari, A., 2014. Zoned monazite and zircon as monitors for the thermal history of granulite terranes: an example from the Central Indian Tectonic Zone. J. Petrol. 55 (3), 585-621.

Bouhallier, H., 1995. Evolution structurale et metamorphic della croute continentale Acrcheenne (craton de Dharwad Inde du Sud) Mem. Doc. Geosciences Rennes 60, 277p.

Bouhallier, H., Choukroune, P., Ballèvre, M., 1993. Diapirism, bulk homogeneous shortening and transcurrent shearing in the Archaean Dharwar craton: the Holenarsipur area, southern India. Precambrian Res. 63 (1-2), 43-58.

Bouhallier, H., Chardon, D., Choukroune, P., 1995. Strain patterns in Archaean dome-andbasin structures: the Dharwar craton (Karnataka, South India). Earth Planet. Sci. Lett. 135 (1-4), 57-75.

Brandt, S., Raith, M.M., Schenk, V., Sengupta, P., Srikantappa, C., Gerdes, A., 2014. Crustal evolution of the Southern Granulite Terrane, South India: new geochronological and geochemical data for felsicorthogneisses and granites. Precambrian Res. 246, 91-122.

Buick, I.S., Hermann, J., Williams, I.S., Gibson, R.L., Rubatto, D., 2006. A SHRIMP U-Pb and LA-ICP-MS trace element study of the petrogenesis of garnet-cordieriteorthoamphibole gneisses from the Central Zone of the Limpopo Belt, South Africa. Lithos 88 (1-4), 150-172.

Chatterjee, N., Banerjee, M., Bhattacharya, A., Maji, A.K., 2010. Monazite chronology, metamorphism-anatexis and tectonic relevance of the mid-Neoproterozoic Eastern Indian Tectonic Zone. Precambrian Res. 179 (1-4), 99-120.

Connolly, J.A.D., 1990. Multivariable phase diagrams: an algorithm based on generalized thermodynamics. Am. J. Sci. 290, 666-718.

Cutts, K.A., Stevens, G., Hoffmann, J.E., Buick, I.S., Frei, D., Münker, C., 2014. Paleo-to Mesoarchean polymetamorphism in the Barberton Granite-Greenstone Belt, South Africa: Constraints from $\mathrm{U}-\mathrm{Pb}$ monazite and $\mathrm{Lu}-\mathrm{Hf}$ garnet geochronology on the tectonic processes that shaped the belt. GSA Bull. 126 (3-4), 251-270.
Diener, J.F., Stevens, G., Kisters, A.F., Poujol, M., 2005. Metamorphism and exhumation of the basal parts of the Barberton greenstone belt, South Africa: Constraining the rates of Mesoarchaean tectonism. Precambrian Res. 143 (1-4), 87-112.

Dziggel, A., Stevens, G., Poujol, M., Anhaeusser, C.R., Armstrong, R.A., 2002. Metamorphism of the granite-greenstone terrane south of the Barberton greenstone belt, South Africa: an insight into the tectono-thermal evolution of the 'lower'portions of the Onverwacht Group. Precambrian Res. 114 (3-4), 221-247.

Engi, M., Lanari, P., Kohn, M.J., 2017. Significant ages-an introduction to petrochronology. Rev. Mineral. Geochem. 83 (1), 1-12.

Ernst, W.G., 1988. Tectonic history of subduction zones inferred from retrograde blueschist PT paths. Geology 16 (12), 1081-1084.

Evans, T.P., 2004. A method for calculating effective bulk composition modification due to crystal fractionation in garnet-bearing schist; implications for isopleth thermobarometry. J. Metamorph. Geol. 22, 547-557.

Fletcher, I.R., McNaughton, N.J., Davis, W.J., Rasmussen, B., 2010. Matrix effects and calibration limitations in ion probe $\mathrm{U}-\mathrm{Pb}$ and Th-Pb dating of monazite. Chem. Geol. 270, 31-44

Foster, G., Parrish, R.R., Horstwood, M.S., Chenery, S., Pyle, J., Gibson, H.D., 2004. The generation of prograde P-T-t points and paths; a textural, compositional, and chronological study of metamorphic monazite. Earth Planet. Sci. Lett. 228 (12), 125-142.

Francois, C., Philippot, P., Rey, P., Rubatto, D., 2014. Burial and exhumation during Archean sagduction in the east Pilbara granite-greenstone terrane. Earth Planet. Sci. Lett. 396, 235-251.

Ganguly, J., Cheng, W.J., Tirone, M., 1996. Thermodynamics of aluminosilicate garnet solid solution: new experimental data, an optimized model, and thermometric applications. Contrib. Mineral. Petrol. 126, 137-151.

Gibson, H.D., Carr, S.D., Brown, R.L., Hamilton, M.A., 2004. Correlations between chemical and age domains in monazite, and metamorphic reactions involving major pelitic phases: an integration of ID-TIMS and SHRIMP geochronology with Y-Th-U X-ray mapping. Chem. Geol. 211 (3-4), 237-260.

Guitreau, M., Mukasa, S.B., Loudin, L., Krishnan, S., 2017. New constraints on the early formation of the Western Dharwar Craton (India) from igneous zircon U-Pb and Lu-Hf isotopes. Precambrian Res. 302, 33-49.

Hallett, B.W., Spear, F.S., 2015. Monazite, zircon, and garnet growth in migmatitic pelites as a record of metamorphism and partial melting in the East Humboldt Range, Nevada. Am. Mineral. 100 (4), 951-972.

Hermann, J., Rubatto, D., 2003. Relating zircon and monazite domains to garnet growth zones: age and duration of granulite facies metamorphism in the Val Malenco lower crust. J. Metamorph. Geol. 21 (9), 833-852.

Herzberg, C., Condie, K., Korenaga, J., 2010. Thermal history of the Earth and its petrological expression. Earth Planet. Sci. Lett. 292 (1-2), 79-88.

Hetherington, C.J., Backus, E.L., McFarlane, C.R., Fisher, C.M., Pearson, D.G., 2017. Origins of textural, compositional, and isotopic complexity in monazite and its petrochronological analysis. Microstructural Geochronology: Planetary Records Down to Atom Scale. vol. 232, p. 63.

Hickmott, D.D., Shimizu, N., 1990. Trace element zoning in garnet from the Kwoiek Area, British Columbia: disequilibrium partitioning during garnet growth? Contrib. Mineral. Petrol. 104 (6), 619-630.

Hokada, T., et al., 2013. An appraisal of Archaean supracrustal sequences in Chitradurga schist belt, western Dharwar Craton, southern India. Precambrian Res. 227, 99-119.

Holland, T.J.B., Powell, R., 1998. An internally consistent thermodynamic data set for phases of petrological interest. J. Metamorph. Geol. 16 (3), 309-343.

Ireland, T.R., 1995. Ion microprobe mass spectrometry: techniques and applications in cosmochemitry, geochemistry, and geochronology. Adv. Anal. Geochem. $1-118$.

Ireland, T.R., Gibson, G.M., 1998. SHRIMP monazite and zircon geochronology of highgrade metamorphism in New Zealand. J. Metamorph. Geol. 16 (2), 149-167.

Ireland, T.R., Williams, I.S., 2003. Considerations in zircon geochronology by SIMS. Rev. Mineral. Geochem. 53 (1), 215-241.

Ireland, T.R., Wooden, J.L., Persing, H., Ito, B., 1999. Geological applications and analytical development of the SHRIMP-RG. EOS Trans. Am. Geophys. Union 80 (46), F1117.

Janardhan, A.S., Srikantappa, C., Ramaohandra, H.M., 1978. The Sargur schist complex-an Archaean high-grade terrain in southern India. Dev. Precambrian Geol. 1, 127-149.

Janardhan, A.S., Newton, R.C., Hansen, E.C., 1982. The transformation of amphibolite facies gneiss to charnockite in southern Karnataka and northern Tamil Nadu, India. Contrib. Mineral. Petrol. 79 (2), 130-149.

Jayananda, M., Kano, T., Peucat, J.J., Channabasappa, S., 2008. 3.35 Ga komatiite volcanism in the western Dharwar craton, southern India: constraints from $\mathrm{Nd}$ isotopes and whole-rock geochemistry. Precambrian Res. 162 (1), 160-179.

Jayananda, M., Tsutsumi, Y., Miyazaki, T., Gireesh, R.V., Kapfo, K.U., Hidaka, H., Kano, T., 2013. Geochronological constraints on Meso-and Neoarchean regional metamorphism and magmatism in the Dharwar craton, southern India. J. Asian Earth Sci. 78, $18-38$.

Jayananda, M., Chardon, D., Peucat, J.J., Fanning, C.M., 2015. Paleo-to Mesoarchean TTG accretion and continental growth in the western Dharwar craton, Southern India: constraints from SHRIMP U-Pb zircon geochronology, whole-rock geochemistry and NdSr isotopes. Precambrian Res. 268, 295-322.

Kelsey, D.E., Clark, C., Hand, M., 2008. Thermobarometric modelling of zircon and monazite growth in melt-bearing systems: examples using model metapelitic and metapsammitic granulites. J. Metamorph. Geol. 26 (2), 199-212.

Kohn, M.J., Malloy, M.A., 2004. Formation of monazite via prograde metamorphic reactions among common silicates: implications for age determinations. Geochim. Cosmochim. Acta 68 (1), 101-113. 
Korenaga, J., 2013. Initiation and evolution of plate tectonics on Earth: theories and observations. Annu. Rev. Earth Planet. Sci. 41, 117-151.

Kretz, R., 1983. Symbols for rock-forming minerals. Am. Mineral. 68 (1-2), 277-279.

Lancaster, P.J., Dey, S., Storey, C.D., Mitra, A., Bhunia, R.K., 2015. Contrasting crustal evolution processes in the Dharwar craton: insights from detrital zircon $\mathrm{U}-\mathrm{Pb}$ and $\mathrm{Hf}$ isotopes. Gondwana Res. 28 (4), 1361-1372.

Li, S.S., Santosh, M., Palin, R.M., 2018. Metamorphism during the ArcheanPaleoproterozoic transition associated with microblock amalgamation in the Dharwar Craton, India. J. Petrol. 59 (12), 2435-2462.

Ludwig, K.R., 2001. SQUID 1.02: A User's Manual. Berkeley Geochronological Center.

Ludwig, K.R., 2003. User's Manual for Isoplot, v. 3.0, A Geochronological Toolkit for Microsoft Excel. Berkeley Geochronological Center (Special Publication, (4)).

Macgregor, A.M., 1951. Some milestones in the Precambrian of Southern Rhodesia. Proc. Geol. Soc. South Afr. 54, 27-71.

Maibam, B., Goswami, J.N., Srinivasan, R. 2011. Pb-Pb zircon ages of Archaean metasediments and gneisses from the Dharwar craton, southern India: implications for the antiquity of the eastern Dharwar craton. J. Earth Syst. Sci. 120 (4), 643-661.

Marmo, B.A., Clarke, G.L., Powell, R., 2002. Fractionation of bulk rock composition due to porphyroblast growth; effects on eclogite facies mineral equilibria, Pam Penninsula, New Caledonia. J. Metamorph. Geol. 20, 151-165.

Michaut, C., Jaupart, C., 2007. Secular cooling and thermal structure of continental lithosphere. Earth Planet. Sci. Lett. 257 (1-2), 83-96.

Montel, J.M., Foret, S., Veschambre, M., Nicollet, C., Provost, A., 1996. Electron microprobe dating of monazite. Chem. Geol. 131 (1-4), 37-53.

Moyen, J.F., Stevens, G., Kisters, A., 2006. Record of mid-Archaean subduction from metamorphism in the Barberton terrain, South Africa. Nature 442 (7102), 559.

Mukherjee, R., Mondal, S.K., Frei, R., Rosing, M.T., Waight, T.E., Zhong, H., Kumar, G.R., 2012. The 3.1 Ga Nuggihalli chromite deposits, Western Dharwar craton (India): geochemical and isotopic constraints on mantle sources, crustal evolution and implications for supercontinent formation and ore mineralization. Lithos 155, 392-409.

Naqvi, S.M., Mohan, M.R., Prathap, J.R., Sarma, D.S., 2009. Adakite-TTG connection and fate of Mesoarchaean basaltic crust of Holenarsipur Nucleus, Dharwar Craton, India. J. Asian Earth Sci. 35 (5), 416-434.

Newton, R.C., Charlu, T.V., Kleppa, O.J., 1980. Thermochemistry of the high structural state plagioclases. Geochem. Cosmochim. Acta 44, 933-941.

Nicoli, G., Stevens, G., Moyen, J.F., Frei, D., 2015. Rapid evolution from sediment to anatectic granulite in an Archean continental collision zone: the example of the Bandelierkop Formation metapelites, South Marginal Zone, Limpopo Belt, South Africa. J. Metamorph. Geol. 33 (2), 177-202.

Nutman, A.P., Chadwick, B., Ramakrishnan, M., Viswanatha, M.N., 1992. SHRIMP U-Pb ages of detrital zircon in Sargur supracrustal rocks in western Karnataka, southern India. J. Geol. Soc. India 39 (5), 367-374.

Otamendi, J.E., de La Rosa, J.D. Douce, A.E.P., Castro, A., 2002. Rayleigh fractionation of heavy rare earths and yttrium during metamorphic garnet growth. Geology 30 (2), 159-162.

Parrish, R.R., 1990. U-Pb dating of monazite and its application to geological problems. Can. J. Earth Sci. 27 (11), 1431-1450.

Peucat, J.J., Mahabaleswar, B., Jayananda, M., 1993. Age of younger tonalitic magmatism and granulitic metamorphism in the South Indian transition zone (Krishnagiri area); comparison with older Peninsular gneisses from the Gorur-Hassan area. J. Metamorph. Geol. 11 (6), 879-888.

Peucat, J.J., Bouhallier, H., Fanning, C.M., Jayananda, M., 1995. Age of the Holenarsipur greenstone belt, relationships with the surrounding gneisses (Karnataka, South India). J. Geol. 103 (6), 701-710.

Powell, R., Holland, T.J.B., 1999. Relating formulations of the thermodynamics of mineral solid solutions; activity modeling of pyroxenes, amphiboles, and micas. Am. Mineral. $84(1-2), 1-14$.

Putnis, A., 2002. Mineral replacement reactions: from macroscopic observations to microscopic mechanisms. Mineral. Mag. 66 (5), 689-708.

Pyle, J.M., Spear, F.S., Rudnick, R.L., McDonough, W.F., 2001. Monazite-xenotime-garnet equilibrium in metapelites and a new monazite-garnet thermometer. J. Petrol. 42 (11), 2083-2107

Raase, P., Raith, M., Ackermand, D., Lal, R.K., 1986. Progressive metamorphism of mafic rocks from greenschist to granulite facies in the Dharwar Craton of South India. J. Geol. 94 (2), 261-282.

Radhakrishna, B.P., Naqvi, S.M., 1986. Precambrian continental crust of India and its evolution. J. Geol. 94 (2), 145-166.

Raith, M., et al., 1982. The Archean craton of southern India: metamorphic evolution and P-T conditions. Geol. Rundsch. 71 (1), 280-290.
Ramakrishnan, M., Viswanatha, M.N., 1981. Hole Narsipur belt. Mem. Geol. Surv. India $112,115-142$

Røhr, T.S., Corfu, F., Austrheim, H., Andersen, T.B., 2004. Sveconorwegian U-Pb zircon and monazite ages of granulite-facies rocks, Hisarøya, Gulen, Western Gneiss Region, Norway. Nor. J. Geol. 84, 251-256.

Roberts, N.M., Santosh, M., 2018. Capturing the Mesoarchean emergence of continental crust in the Coorg Block, southern India. Geophys. Res. Lett. 45 (15), 7444-7453.

Rollinson, H.R., Windley, B.F., Ramakrishnan, M., 1981. Contrasting high and intermediate pressures of metamorphism in the Archaean Sargur Schists of southern India. Contrib. Mineral. Petrol. 76 (4), 420-429.

Rubatto, D., Williams, I.S., Buick, I.S., 2001. Zircon and monazite response to prograde metamorphism in the Reynolds Range, Central Australia. Contrib. Mineral. Petrol. 140 (4), 458-468.

Rubatto, D., Hermann, J., Buick, I.S., 2006. Temperature and bulk composition control on the growth of monazite and zircon during low-pressure anatexis (Mount Stafford, Central Australia). J. Petrol. 47 (10), 1973-1996.

Rubatto, D., Chakraborty, S., Dasgupta, S., 2013. Timescales of crustal melting in the higher Himalayan Crystallines (Sikkim, Eastern Himalaya) inferred from trace elementconstrained monazite and zircon chronology. Contrib. Mineral. Petrol. 165 (2), 349-372.

Santosh, M., Li, S.S., 2018. Anorthosites from an Archean continental arc in the Dharwar Craton, southern India: implications for terrane assembly and cratonization. Precambrian Res. 308, 126-147.

Sarma, D.S., McNaughton, N.J., Belusova, E., Mohan, M.R., Fletcher, I.R., 2012. Detrital zircon U-Pb ages and Hf-isotope systematics from the Gadag Greenstone Belt: Archean crustal growth in the western Dharwar Craton, India. Gondwana Res. 22 (3-4), $843-854$.

Schärer, U., 1984. The effect of initial ${ }^{230} \mathrm{Th}$ disequilibrium on young U-Pb ages: the Makalu case, Himalaya. Earth Planet. Sci. Lett. 67 (2), 191-204.

Sizova, E., Gerya, T., Stüwe, K., Brown, M., 2015. Generation of felsic crust in the Archean: a geodynamic modeling perspective. Precambrian Res. 271, 198-224.

Sizova, E., Gerya, T., Brown, M., Stüwe, K., 2018. What drives metamorphism in early Archean greenstone belts? Insights from numerical modeling. Tectonophysics 746 587-601.

Smye, A.J., Greenwood, L.V., Holland, T.J.B., 2010. Garnet-chloritoid-kyanite assemblages: eclogite facies indicators of subduction constraints in orogenic belts. J. Metamorph. Geol. 28 (7), 753-768.

Srikantappa, C., Raith, M., Ackermand, D., 1985. High-grade regional metamorphism of ultramafic and mafic rocks from the Archaean Sargur Terrane, Karnataka, South India. Precambrian Res. 30 (3) (189-21).

Stern, R.A., Berman, R.G., 2001. Monazite U-Pb and Th-Pb geochronology by ion microprobe, with an application to in situ dating of an Archean metasedimentary rock. Chem. Geol. 172 (1-2), 113-130.

Stern, R.J., Leybourne, M.I., Tsujimori, T., 2016. Kimberlites and the start of platetectonics. Geology 44, 799-802.

Swami Nath, J., Ramakrishnan, M., 1981. Early Precambrian supracrustals of southern Karnataka.(A) present classification and correlation. Mem. Geol. Surv. India 112, p350.

Van Kranendonk, M.J., 2011a. Onset of plate tectonics. Science 333 (6041), 413-414.

Van Kranendonk, M.J., 2011b. Cool greenstone drips and the role of partial convective overturn in Barberton greenstone belt evolution. J. Afr. Earth Sci. 60 (5), 346-352.

Van Kranendonk, M.J., Kröner, A., Hoffmann, J.E., Nagel, T., Anhaeusser, C.R., 2014. Just another drip: Re-analysis of a proposed Mesoarchean suture from the Barberton Mountain Land, South Africa. Precambrian Res. 254, 19-35.

Vance, D., Mahar, E., 1998. Pressure-temperature paths from P-T pseudosections and zoned garnets: potential, limitations and examples from the Zanskar Himalaya, NW India. Contrib. Mineral. Petrol. 132 (3), 225-245.

Waldbaum, D.R., Thompson, J.B., 1968. Mixing properties of sanidine crystalline solutions II. Calculations based on volume data. Am. Mineral. 53 (11-12), 2000-2017.

Warren, C.J., Greenwood, L.V., Argles, T.W., Roberts, N.M., Parrish, R.R., Harris, N.B., 2018 Garnet-monazite rare earth element relationships in sub-solidus metapelites: a case study from Bhutan. Geol. Soc. Lond. Spec. Publ. 478 (SP478-1).

Williams, I.S., Compston, W., Black, L.P., Ireland, T.R., Foster, J.J., 1984. Unsupported radiogenic $\mathrm{Pb}$ in zircon: a cause of anomalously high $\mathrm{Pb}-\mathrm{Pb}, \mathrm{U}-\mathrm{Pb}$ and Th-Pb ages. Contrib. Mineral. Petrol. 88 (4), 322-327.

Williams, M.L., Jercinovic, M.J., Hetherington, C.J., 2007. Microprobe monazite geochronology: understanding geologic processes by integrating composition and chronology Annu. Rev. Earth Planet. Sci. 35, 137-175. 